Board of Governors of the Federal Reserve System

International Finance Discussion Paper

Number 604

March 1998

Was China the First Domino? Assessing Links between China and the Rest of Emerging Asia

John Fernald, Hali Edison, and Prakash Loungani

NOTE: International Finance Discussion Papers are preliminary materials circulated to stimulate discussion and critical comment. References to International Finance Discussion Papers (other than an acknowledgment that the writer has had access to unpublished material) should be cleared with the author or authors. Recent IFDPs are available on the Web at www.bog.frb.fed.us. 


\title{
Was China the First Domino? Assessing Links between China and the Rest of Emerging Asia
}

\author{
John Fernald, Hali Edison, and Prakash Loungani*
}

\begin{abstract}
We assess links between China and the rest of emerging Asia. Some commentators have argued that China's apparent devaluation in 1994 may have contributed to the Asian financial crisis. We argue that the devaluation was not economically important: The more-relevant exchange rate was a floating rate that was not devalued, and high Chinese inflation has led to a very sharp real appreciation of the currency. Although in principle, export competition with China could nevertheless have placed pressure on other Asian exporters, we argue that the striking feature of the data is the common movement between export growth from China and from other developing Asian economies. To the extent there is evidence of export competition, it is the period from about 1989 to 1993: China's exchange rate depreciated sharply, Chinese export growth exceeded export growth of other Asian economies, and the composition of Asian exports (measured by export shares of various goods to the United States and other industrial economies) changed substantially. Finally, we speculate on the effects of the Asian crisis on China's prospects. China's economic growth is likely to slow because of increased trade competition as a result of the devaluation of other Asian currencies, and because of reduced capital inflows. In addition, these reduced inflows are likely to reduce job creation in the non-state sector, and hence make enterprise restructuring more difficult in China.
\end{abstract}

* The authors are economists in the International Finance Division of the Federal Reserve Board. Please address correspondence to John Fernald at Stop 20, Federal Reserve Board, Washington DC 20551, or fernaldj@frb.gov. We thank Lewis Alexander, Caroline Freund, Dale Henderson, Steve Kamin, Nathan Sheets, Ted Truman, and seminar participants at the January 1998 American Economic Association meetings for helpful comments on an earlier draft. We also thank Oliver Babson, Jennifer Cascone, Adam LaVier, Michael Sharkey, and Katherine Vanderhook for help with data and charts. The views in this paper are solely the responsibility of the authors and should not be interpreted as reflecting the views of the Board of Governors of the Federal Reserve System or of any other person associated with the Federal Reserve System. 
What are the links between China and other Asian economies? As of March 1998, a crisis in Asian financial and currency markets had reached every major Asian economy outside of China. Press reports, and the speculation of several prominent economists, suggest that competition from China may have contributed to the crisis, and that China will not remain unaffected by the crisis. This paper refutes the former suggestion, but supports the latter.

In particular, we focus on two questions. First, how has China's emergence as a major exporter affected the export growth of other developing Asian economies? Second, through what channels might the current Asian financial crisis propagate to China?

In addressing the first question, we show that a striking feature of the data is the similarity between China's export growth and that of other developing Asian economies, suggesting the importance of common factors driving export demand, rather than the substitution of Chinese for other economies' exports. One implication of this finding is that it is unlikely that export-competition with China was a major contributor to the Asian crisis.

However, we also argue that past may not be prologue. Over the historical period, exchange rates were relatively stable, while the current period is one in which the currencies of many Asian economies have depreciated sharply. Hence, there is much more potential for export-competition than was the case in the past. China may also be affected by channels other than export-competition. For instance, foreign direct investment and other inflows are likely to fall, reducing investment in China. Overall, China therefore remains vulnerable to the Asian flu.

Figure 1 provides a useful starting point for our analysis: It shows two frequently noted, but highly misleading, stylized facts: The top panel shows China's official exchange rate, and its precipitous devaluation at the beginning of 1994; the bottom panel shows a surge in Chinese exports in 1994 and 1995. Based on these observations, several commentators have argued that the Asian currency crisis originated, 
in part, from China's 1994 currency devaluation ${ }^{1}-$ China, according to these analysts, was the first domino to fall in Asia. The devaluation supposedly gave China a competitive advantage relative to other Asian economies, leading to the surge in Chinese exports in 1994 and thereafter. Other Asian countries kept their exchange rates pegged to the U.S. dollar, and hence did not react immediately to China's competitive devaluation. However, over time the effects of the loss in competitiveness accumulated, contributing to growing current account balances and eventually a currency crisis.

By contrast, we argue that both panels of Figure 1 are highly misleading-China was not the first Asian domino. In terms of the exchange rate itself, the argument that China substantially devalued its effective exchange rate in 1994 is misguided. Before 1994, China had a dual foreign exchange market. The top panel of Figure 2 shows the two main exchange rates: Some transactions took place at the official rate (the thin dotted line), while others took place at a floating rate (often called the "swap-market rate," shown with the thick solid line). (China continues to limit convertibility on the capital account, so at least officially, most transactions are trade-related.) On January 1, 1994, China unified the dual rates at the market rate, which required devaluing its official rate by about a third against the U.S. dollar-the value of the renminbi fell from about 17 cents to about 11 cents. $^{2}$ The official rate was then abolished. Before unification, Chinese exporters received an effective marginal rate that was a weighted average of the official and floating rates.

${ }^{1}$ For example, John Makin (1997) claimed that China "devalued its currency by 35 percent," and that its "preemptive devaluation... was the first in a number of events leading to the acute problems in Asia that surfaced this year." Other recent references that link China's 1994 devaluation to the Asian crisis include Bergsten (1997), and articles in the Financial Times (September 17, 1997, p29), Barron's (October 27, 1997, p 17), The Washington Post (November 27, 1997, pB11; and February 4, 1998, p.A18), the Economist (November 22, 1997, p41), Euromoney (December 1997, p. 38), and The New York Times (February 3, 1998, pA31). Huh and Kasa (1997) also discuss the possible role of a Chinese devaluation as trigger for an Asian competitive devaluation (although their story could apply even without a Chinese devaluation in 1994).

${ }^{2}$ The terms "renminbi" and "yuan" are generally used interchangeably to refer to China's currency-the renminbi (literally, "people's money") is the currency, and the yuan is the unit of account. This exchange rate is more commonly quoted in terms of renminbi/dollar, so the devaluation represented an increase from 5.8 to 8.7 renminbi/dollar. 
IMF economists and others generally estimate that before unification, about 80 percent of the weight was on the floating rate, and 20 percent on the official rate. ${ }^{3}$ Hence, despite the enormous devaluation apparent in the official exchange series in January 1997, the effective nominal depreciation relative to the dollar was considerably smaller, about 7 percent.

Moreover, on a real effective basis, the depreciation rapidly reversed itself. The unification of the two markets took place at a time of rapid-and increasing-inflation in China, shown by the thin solid line in the top panel. Consumer price inflation, for example, was 19 percent in 1993 and 26 percent in 1994, before moderating to 10 percent in 1995. The bottom panel of Figure 2 shows China's export-weighted real effective exchange rate. The nominal depreciation at the beginning of 1994 is barely a blip in the upward trend from mid-1993 through 1997, during which time the real exchange rate appreciated more than 60 percent. To the extent that one wants to focus on the competitive effects of China's exchange rate, one needs to focus on the 1989-1993 period, when China's real exchange rate did, in fact, depreciate steadily. The focus on 1994 gets the timing wrong. ${ }^{4}$

Nevertheless, even if the 1994 devaluation was largely illusory, it may be that China's strong export performance in 1994 and 1995 has contributed to the present crisis, to the extent that it has curtailed the export growth of other Asian countries. For example, China's strong export performance may reflect economic reforms implemented in the first half of the 1990s, and rapid investment in export-oriented

${ }^{3}$ See, for example, Khor (1993), Tseng et al. (1994, p5), and the extended discussion of the exchange system in Mehran et al. (1996, pp. 55-61). Khor, in particular, argues that the 80-percent figure appropriately measures the marginal exchange-rate incentives faced by an exporter, since it represents the proportion of foreign exchange earnings that an exporter was allowed to retain for his or her own use, including selling on the floating-rate market.

${ }^{4}$ The relative unimportance of China's 1994 devaluation is well known to China scholars, as confirmed in numerous informal discussions in 1994, and again in 1997/98. Since writing the first draft of this paper in December 1997, we became aware of Liu et al (1998), who make a similar argument about the unimportance of the 1994 devaluation. 
industries, rather than a depreciation of the exchange rate.

Figure 3, however, shows striking evidence against this view. The top panel shows export growth from Greater China (defined to be China plus Hong Kong) and from the rest of developing Asia to the world as a whole; the bottom panel shows export growth to industrial economies. In both panels, the data used are from trading partner statistics. ${ }^{5}$

What is striking is the similarity in export growth between Greater China and the rest of developing Asia, including in the period 1994 to 1996: both show high growth in 1994 and 1995, and a slowdown in 1996. This suggests that common factors-such as growth in developed economies, movements in the world price of key exports such as semiconductors, and movements in the yen-dollar rate-were probably more important determinants for Asian exports than was competition with Greater China. Discussions of China's export performance tend to emphasize factors idiosyncratic to China, such as economic reform initiatives, rapid investment, or tax incentives; but these discussions appear to miss the common shocks that hit all Asian economies in 1996.

The bottom panel of Figure 3 shows exports from Greater China and the rest of developing Asia to industrial countries. Again, these two series move fairly closely together, and hence clearly seem to be reacting to common shocks, such as demand by industrial countries. However, the differences are considerably more pronounced than in the top panel. The greatest differences came in early 1990s, particularly between 1990 and 1993, when import growth by industrial countries from Greater China grew nearly 10 percent faster than from the rest of developing Asia. In the first nine months of 1997, the gap widened again, with export growth 11 percent faster from Greater China than from other developing Asian economies.

To summarize, Figure 3 tells a simple-but to us a fairly compelling-graphical story. Greater

5 As we discuss at greater length in the next section, it makes economic sense to look at China and Hong Kong together, and statistical sense to use trading-partner imports. 
China's export growth has a strong positive correlation with export growth from the rest of Asia. This by itself does not disprove the existence of competition between the two, but it does raise the hurdle for demonstrating that export-competition is a first-order effect. The overall pattern of export competition from China seems unlikely to have been an important factor contributing to the 1997 Asian crisis. At the margin, China's strong trade performance in 1997 may have placed pressure on other Asian economies, but it seems likely that most of the factors contributing to the crisis pre-date this very recent export surge by China.

\section{A Roadmap to the Remainder of the Paper}

Figure 3 serves as a point of departure for the next two sections of the paper. Section I discusses some of the trade statistics that go into Figure 3 in greater detail. In particular, we present the case for (1) treating Chinese and HK as an integrated economic unit even before the handover, and (2) using trading partner statistics (i.e. recorded imports from Greater China) instead of China's own export statistics.

Section II subjects the simple graphical story of Figure 3 to some "stress tests." We look at disaggregated trade data by region and industry to see if the aggregate data are masking somewhat more intense competition between Greater China and other Asian countries in more narrowly defined markets. We find that over the period 1989 to 1993, Greater China export shares did increase in many markets, largely at the expense of the Asian NIEs (Korea, Singapore and Taiwan). In contrast, the period 1993 to 1996 is characterized by relative stability in market shares across Greater China, the NIEs, and the major ASEAN economies. Hence, China's robust export performance in 1994 and 1995-and the alleged devaluation of 1994-did not translate into major gains in market share.

Another finding that emerges from Section II is very difficult to generate a negative correlation between Chinese exports and those of other Asian economies, even after controlling for various common global factors. We know from Figure 3 that the correlation between Greater China's export growth and that of other Asian economies is likely to be strongly positive (as in fact its turns out to be); nevertheless, we 
might expect that once we control for common factors, such as developed country growth, stronger exports by China will be associated with weaker exports by other Asian economies. (After all, we would expect that in the absence of Greater China, exports of Asian economies might have grown even faster in the 1990s.) However, after estimating a standard trade model to control for obvious common global factors, we still cannot get a negative relationship between Chinese export growth and export growth of other Asian economies. Although this may reflect an inability to control completely for global factors that drive trade, it nevertheless implies that in the data, trade competition with China does not leap out as a significant factor reducing the quantity of Asian exports. Thus, it is difficult to sustain any claim that China's export performance "forced" other Asian economies into an eventual competitive depreciation.

Having argued, in essence, that China was not the first domino to fall in the Asian crisis, Section III then assesses the risks that it will be one of the later dominos to fall. In particular, we explore the channels through which the Asian crisis can affect, and propagate through, China's economy. The crisis is likely to have two effects on Chinese aggregate demand. First, China exports to other Asian countries, so weakness in those economies-and in Japan-will reduce demand for Chinese exports. In addition, as noted earlier, export-competition may be more intense in the future than it has been in the recent past because of the relatively large depreciations of several Asian currencies. Second, foreign direct investment (FDI) and other inflows are likely to fall, reducing investment.

A third effect of the shock is that it makes industrial restructuring more difficult in China. In 1997, China announced plans to restructure state-owned enterprises (SOEs) and reduce their role in the economy. This major shift requires a massive reallocation of labor and capital, which in turn requires substantial investments in new firms. But FDI is a major source of financing for the non-state sector, so any decline in FDI is likely to make this reallocation more difficult. In other words, downsizing SOEs requires destroying existing jobs and laying off workers, a politically difficult step. This downsizing is easier if new jobs are being created, and the pace of job creation is likely to slow because of reductions in the financing available 
to the non-state sector.

\section{Stylized Facts about Chinese Trade}

This section analyzes trade statistics for Greater China--defined as China plus Hong Kong ${ }^{6}$--in some detail. The two main points that emerge from the analysis are the following:

- It makes economic sense to combine China and Hong Kong trade data (even before the handover) because it is conceptually difficult to differentiate the contributions of Chinese and Hong Kong firms.

- It makes statistical sense to focus on trading partner imports, because these statistics may be more reliable, and less subject to double counting.

Substantiating these points takes a fair bit of work; readers who are not interested in the nuts and bolts of the trade statistics can skip to the next section without losing the main argument of the paper.

Much of China's trade passes through Hong Kong. Hong Kong plays an important role in marketing and distributing Chinese goods, as sundry goods may be shipped there from all over China, sorted, and then shipped on to particular ports around the world. Moreover, it may often be difficult to distinguish the contribution of China, per se, from the contribution of Hong Kong. Hong Kong entrepreneurs often use their specialized knowledge about operating in China to set up factories in China, or contract with Chinese companies to provide goods. The goods, which may or may not pass through Hong Kong, are worth more than simply the contract cost of producing them in China, reflecting the value added by the services of Hong Kong firms. Given the complementary nature of China and Hong Kong trade, if our interest is the effect of China's exports on Asia and the world, one should include the effect of Hong Kong. ${ }^{7}$

${ }^{6}$ A more common definition of "Greater China" includes Taiwan as well, but for our purposes, it useful to limit the focus to China plus Hong Kong.

${ }^{7}$ Krugman (1997a) also argues that we should combine China and Hong Kong, on the grounds that conceptually, it is like separating the trade statistics for New York City and the rest of the United 
Because of its entrepot role, Hong Kong statistics distinguish between "domestic exports" and "reexports." A domestic export is manufactured (in whole or in part) in Hong Kong, whereas a re-export is manufactured elsewhere, imported into Hong Kong, and then exported again. Re-exports may nevertheless have substantial value added in Hong Kong-according to Hong Kong customs, they may undergo "diluting, packing, bottling, drying, assembling, sorting, decorating, etc." ${ }^{8}$ Moreover, running a marketing and distribution center in Hong Kong itself adds value to the goods that pass through Hong Kong, as sundry goods may be shipped there from all over China, sorted, and then shipped on to particular ports around the world, often because of the marketing efforts of Hong Kong firms.

Hong Kong statistics indicate that these services add considerable value. In 1996, for example, the value of Hong Kong's re-exports originating from China exceed Hong Kong's total imports from China by 25 percent. ${ }^{9}$ This 25 percent figure understates the value added in Hong Kong, since some of those imports are retained in Hong Kong; Hong Kong no longer measures "retained imports" in its statistics, but Hong Kong merchandise statistics include imports of raw materials, electricity, food, and water - much of which

States.

8 According to the Annual Review of Hong Kong External Trade 1996, (from the included CD ROM), "a "domestic export" from Hong Kong is the natural produce of Hong Kong or the product of a manufacturing process in Hong Kong which has changed permanently the shape, nature, form or utility of the basic materials used in manufacture. Processes such as diluting, packing, bottling, drying, assembling, sorting, decorating, etc., do not confer Hong Kong origin. A "re-export" is a product which has previously been imported into Hong Kong and which is re-exported without having undergone in Hong Kong a manufacturing process which has changed permanently the shape, nature, form or utility of the product....Goods on a through bill of lading switched in Hong Kong-goods which arrive at Hong Kong under a through bill of lading but depart on a separate bill of lading issued in Hong Kong to cover the onward journey-are treated as imports into Hong Kong on arrival and as re-exports from Hong Kong on departure."

9 Annual Review of Hong Kong External Trade 1996, Table 23. 
come from China and remain in Hong Kong. ${ }^{10,11}$

There are at least two concerns with using the official export data of China and Hong Kong. First, China's statistical system has undergone considerable improvements over time, but may still be imperfect. As a result, Chinese exports may not be accurately measured, or may not be measured consistently over time. Second, summing Chinese and Hong Kong exports may lead to double counting, given that many of Hong Kong's "exports" are already counted in China's exports. Until 1992, China recorded exports by immediate, not ultimate, destination: Exports that passed through Hong Kong on their way to the United States, say, were recorded as an export to Hong Kong. In this case, one could avoid double counting in measuring exports to the rest of the world from Greater China by summing Chinese exports that were not to Hong Kong with Hong Kong exports that were not to China. Since 1992, however, China has tried to measure the ultimate destination of exports, so goods that pass through Hong Kong may be counted twice.

A solution to these two problems is to use imports of the rest of the world as a measure of Greater China's exports. This has two advantages. First, many other countries have statistical systems that are better established, and perhaps more reliable, than China's. Second, it avoids the double-counting problem, since importers only allocate their imports to one country of origin. Note that importers may have trouble distinguishing imports from China and Hong Kong. For example, Lardy (1994) argues that U.S. import data incorrectly include the value added in Hong Kong in U.S. imports from China. If we focus on China plus Hong Kong, it does not matter whether the U.S. statistics record the economy of origin correctly, as long as

${ }^{10}$ Until 1992, the Annual Review of Hong Kong External Trade reported retained earnings as the difference between imports and re-exports by origin. This measure explicitly did not account for the value of any services performed in Hong Kong. For China, this measure of retained imports therefore had become increasingly negative.

${ }^{11}$ Feenstra et al (1998) use highly disaggregated trade data from Hong Kong and China in order to allow the markup to differ by ultimate destination; for the United States, for example, their preferred estimate is an average markup between 1988 and 1995 of 26 percent. See also the discussion in Fung (1996) and Lardy (1994, p. 77). 
they record it accurately as originating in Greater China.

Tables 1 and 2 show China and Hong Kong's direction of trade, as measured by China and Hong Kong (columns (1) to (3)), and by their trading partners (columns (1a)-(3a)). Comparing the corresponding columns confirms two facts we expected, given Hong Kong's role as an entrepot for China: (I) For almost all regions, China's recorded exports are far smaller than that region's recorded imports from China, and (ii) for almost all regions, Hong Kong's recorded exports are far greater than that region's recorded imports. The differences appear largest for industrial countries, shown in line 4 of each panel: China's exports of $\$ 82$ billion compare with industrial country imports of $\$ 139$ billion, and Hong Kong's exports of $\$ 84$ billion compare with industrial country imports of $\$ 30$ billion.

The third column sums exports of, and imports from, China and Hong Kong. Comparing the reported exports to the reported imports indicates that for all of the regions shown, the summed data are remarkably similar. For example, line 4 shows that China and Hong Kong record exports to industrial countries of $\$ 166$ billion, compared with industrial country imports of $\$ 170$ billion from China and Hong Kong. Line 9 shows that China and Hong Kong recorded exports to the world (excluding Chinese exports to Hong Kong and Hong Kong exports to China) of \$237 billion, compared with imports of the world as a whole of $\$ 232$ billion. If there were no double counting, we would expect recorded exports to be slightly smaller than recorded imports because of the cost of transporting the goods. Hence, some double counting probably exists, although it does not seem to be large.

How much of China's trade passes through Hong Kong? Chinese statistics will under-represent this share, since they now try to record the ultimate destination of goods rather than the intermediate destination in Hong Kong. However, we can look at Hong Kong's imports from China, which amounted to \$74 billion in 1996 (line 9, column 1). This represents nearly half of China's total exports of \$151 billion (line 11, column 1).

Suppose we assume that all of Hong Kong's imports from China are subsequently re-exported, and 
exclude them. We then expect that China's total exports should compare closely with world imports (excluding Hong Kong imports) of Chinese goods. Line 7 of the bottom panel shows that the world (excluding Hong Kong) recorded imports of \$181 billion from China, compared with China's total exports of $\$ 151$ billion. This clearly demonstrates an inconsistency-the difference between these two numbers, $\$ 30$ billion (20 percent of exports), is too large to reflect simply the c.i.f. adjustment alone. Moreover, if Hong Kong retains some Chinese imports, then the problem is even worse, since the Chinese goods that go to the rest of the world is less than $\$ 151$ billion. ${ }^{12}$ One possible explanation is that trading partners allocate much of the value added by Hong Kong firms to Chinese exports. ${ }^{13}$

Now consider column (2) for Hong Kong. In 1996, Hong Kong reported exporting more than \$180 billion, while the world reported importing only \$59 billion from Hong Kong. The vast majority of Hong Kong's recorded exports are re-exports, in which Hong Kong imports the goods, and then re-exports them to other countries, perhaps after some repackaging, but without additional manufacturing. Hong Kong statistics, not shown, indicate that of the $\$ 181$ billion in total exports, $\$ 27$ billion were domestic exports of Hong Kong firms, and $\$ 153$ billion were re-exports. Hence, trading partner imports substantially exceed Hong Kong's domestic exports; trading partners may appropriately capture some of the value added in Hong Kong on Chinese goods.

\footnotetext{
${ }^{12} \mathrm{~A}$ conservative estimate of Hong Kong's retained imports is $\$ 5$ billion. To estimate this, we looked at data on "imports and re-exports by end-use category by main origin," from Table 22 of Annual Review of Hong Kong External Trade 1996, page 78. For consumer goods and capital goods, Hong Kong re-exports more goods of Chinese origin than it imports, consistent with some value added in Hong Kong. For raw materials and semi-manufactures, foodstuffs, and fuels, Hong Kong re-exports fewer goods than it imports. Assuming that Hong Kong adds 20 percent to the value of its re-exports of those three categories, the retained imports of those three goods from China amounts to $\$ 5$ billion.

${ }^{13}$ It is worth noting, however, that the difference between China's recorded exports and the world's (excluding Hong Kong's) imports from China has widened in recent years; until 1990, China reported more exports than the world reported imports. Looking at China plus Hong Kong, there is no clear trend in the difference between Greater China's reported exports and the world's imports from Greater China. So for this explanation to be correct, the world must now allocate imports to China that they used to allocate to Hong Kong.
} 
Table 2 shows the origin of Greater China's imports. The import data match trading partner's recorded exports reasonably well, although again the figures match better for Greater China than for China and Hong Kong separately. For China plus Hong Kong, in column (3), the numbers are fairly close, differing by an amount that could be consistent with the c.i.f. adjustment ( $\$ 230$ billion in world exports, compared with $\$ 256$ billion in Greater China imports).

Table 3 shows Greater China's trade balance with the world, and regions of the world. Using either Greater China's data, or trading partner data, give comparable results for the sum in column (3). Given the differences from Table 1, there are large differences in whether the balances are allocated to China or Hong Kong-the world claims that China had a surplus of $\$ 86$ billion, while Hong Kong had a deficit of $\$ 84$ billion.

The data do not support the common conception that China has been running large trade surpluses in recent years. Line 9 shows that China and Hong Kong recorded a combined trade deficit with the rest of the world of $\$ 19$ billion. Even trading partner data shows that Greater China had approximately balanced trade - Greater China's surplus was $\$ 2$ billion in 1996. (Note that the c.i.f. adjustments should make Greater China's exports smaller than world imports, while also making world exports smaller than Greater China's imports. Hence, Greater China's recorded trade balance should be lower with its own statistics than with its trading partner statistics.) Both panels show that Greater China runs a large trade surplus with industrialized countries, especially the United States (\$33 billion according to China and Hong Kong; \$39 billion according to the United States), and a large trade deficit with non-Japan Asia (a deficit of \$44 billion in both panels, line 5). The deficit with Asia is largest with Taiwan and Korea; both economies have increasingly located production in China, to which they export components, process them, and then export them to industrial countries.

Figure 4 provides time series evidence on the growth in China and Hong Kong's reported exports (the thin line in the three panels), and the world's reported imports (the thick line). We know from Table 
1 that the levels of the two sets of statistics are very different for China and Hong Kong separately, but similar for China plus Hong Kong. Figure 3 shows that the same general conclusion applies in growth rates.

The top panel focuses on China alone. The thick solid line shows growth in world imports from China, excluding Hong Kong's imports from China, and is very similar to the dashed line, which includes Hong Kong's imports from China. This similarity suggests that Hong Kong's imports from China are close to being a fixed proportion of world (excluding Hong Kong) imports from China. These two series clearly comove with China's recorded export growth, the thin line, but the comovement is far from perfect. World import growth exceeded China's export growth every year from 1987 through 1993. However, world statistics are less volatile thereafter, showing less of a surge in 1994, less of a decline in 1996, and less of a rebound in $1997 . .^{14}$

The middle panel shows export growth from Hong Kong. The thick solid line shows growth in world imports from Hong Kong, while the thin solid line shows Hong Kong's recorded total exports. Since the mid-1980s, these series have diverged substantially. The short dashed lines show Hong Kong re-exports, whereas the long dashed line shows Hong Kong domestic exports. Particularly since 1990, trading partner imports have the closest association with domestic exports, but the fit is far from perfect (the correlation is 0.54 , with a t-statistic of about 1.4).

The bottom panel shows exports for Greater China, defined to exclude trade between China and Hong Kong. Greater China's exports match trading-partner imports very closely. The trading partner data, the solid line, shows a pronounced peak in 1995- not the pronounced peak in 1994 that was apparent in China's reported data. However, even China and Hong Kong data, the dashed line, do not show a

${ }^{14}$ Anecdotal evidence suggests that Chinese exports are highly responsive to various tax incentives, such as variations in the VAT rebate on exports. It may be that what is particularly sensitive is the time when exports are recorded - producers may ship goods to Hong Kong to take advantage of the incentives, and the goods wait in Hong Kong for variable amounts of time; or producers may collude with customs agents to record exports early or late. 
pronounced peak in 1994, but show relatively high, sustained growth from 1993 through $1995 .{ }^{15}$

Finally, for completeness, Figure 5 shows time series evidence on Greater China's import growth and trade balance. (As usual, we exclude trade between China and Hong Kong.) The top panel shows that trading-partner data match Greater-China's import data almost perfectly; the correlation is 0.96 . The bottom panel shows Greater China's trade balance. Even using rest-of-the-world data, China and Hong Kong together tend to have approximately balanced trade, and in recent years have more often run deficits than surpluses. In the first three-quarters of 1997, however, trading partner data indicate that China and Hong Kong ran a sizeable trade surplus, amounting to roughly 3 percent of Greater-China GDP. China and Hong Kong statistics, shown by the dashed line, still show a deficit in 1997, though very small.

Why has China's supposed trade surplus received such attention in recent years, when the data do not show large surpluses until 1997? In part, this may reflect the regional composition of the trade balance: As suggested by Table 3, Greater China runs a large trade surplus with industrial countries, and a large trade deficit with other developing countries.

\section{Analysis of Export-Competition among Asian Economies}

As noted in the introduction, Figure 3 shows that there is strong co-movement between China's export growth and the export growth of other Asian economies. This suggests that common factors-such as growth in industrial countries-are driving the export performance of both China and other Asian countries. Nevertheless, the evidence presented in that figure may conceal competition among Asian countries in particular geographic markets or in particular industries. It may also be the case that once the

${ }^{15}$ In 1993, when the statistics match relatively poorly, the import statistics are more accurate. Although revisions to the statistical system-recording the ultimate rather than the immediate destination for exports-supposedly took place during 1992, the data suggest the main adjustment came in 1993: Exports to Hong Kong fell sharply that year, and China's exports to Hong Kong relative to Hong Kong's imports from China fell from about 80 percent to about 40 percent. Hence, there was a one-time increase that year in the amount of double-counting in the combined export statistics. 
influence of common factors is accounted for, the relationship between China's export growth and export growth in other Asian countries is actually negative. This section investigates these possibilities.

For the analysis in this section, the Asian countries considered here have been classified into one of three groups: (1) Greater China (China and HK), (2) the NIEs (Korea, Singapore, and Taiwan), and (3) the ASEAN-4 (Indonesia, Malaysia, Philippines and Thailand).

\section{A. Competition in Particular Markets and Industries}

We begin by comparing the export performance of these three groups in different geographical regions and in different industries. What we are looking for is evidence that points to "export competition," which we define for present purposes as "shifts in market share" across the three groups. In particular, we want to see if Greater China's market share has increased markedly in a particular region or industry. Note that by focusing on shares in particular markets we are stacking the deck in favor of the export-competition view. A country may have its share in a particular market decline without necessarily experiencing a decline in the level of its exports to that market. It may also be losing market share in one market but gaining it in another.

Our analysis leads to three conclusions:

- $\quad$ Over the period 1989 to 1993, Greater China did gain market share in many markets. This is consistent with our suggestion that the substantial real depreciation of the renminbi may have helped China's exports over this period.

- In contrast, the period 1993 to 1996 is characterized by relative stability in market shares across the three groups. Hence, China's robust export performance in 1994 and 1995 did not translate into major gains in market share.

- China's gains have come largely at the expense of the NIEs rather than the ASEAN-4.

\section{Competition in the U.S. Market}

Our analysis is based on three-digit industry level data published by the BEA. The figures in Table 
4 provide the "market shares" of the three groups in the U.S. market in 1989, 1993 and 1996. The total exports of these countries to the United States have been scaled up so that they add up to 100. As shown in column (1) below, in 1989 China and Hong Kong together accounted for about a quarter of total exports to the United States from the three groups. By 1993, Greater China's share had increased to a third. China alone nearly doubled its share of the U.S. market, helped perhaps by the real depreciation of the renminbi over this period. The ASEAN-4 group also increased its market share, but by a smaller magnitude than the increase in China's share. Correspondingly, the share of the NIEs fell from 59 percent to 44 percent. There is, therefore, some evidence of "competition"-shifts in market share-among the three groups over the period 1989 to 1993.

By contrast, the period between 1993 and 1996 is one of virtual stability in market shares. The shares of Greater China and ASEAN-4 inch up over this period at the expense of the NIEs. The evidence, therefore, does not point to Chinese export growth in 1994 and 1995 leading to a significant expansion of Greater China's market share in the U.S. market.

It may be argued that the evidence presented in Table 4, which was for an aggregate of all industries, masks changes in market shares in particular industries. Our analysis of data for the 48 industries that make up the aggregate shows that is not the case. In Table 5 we show examples of our analysis for key industries, industry 213 (computers, peripherals and semi-conductors) and industry 400 (apparel, footwear and household products).

First consider the changes in industry 213. Here, the market share of China alone rose from essentially zero in 1989 to 5 percent in 1996; however, most of this increase appears to have come at the expense of Hong Kong. When the two are combined, their market share increases only slightly over the period. The share of ASEAN-4 increases somewhat more substantially, with a corresponding fall in the share of the NIEs. There is little evidence that the period 1993 to 1996 is characterized by greater shifts in market shares than the earlier period 1989 to 1993. 
The story in the case of industry 400 is a bit different. Here, Greater China does experience a big increase in market share between 1989 and 1996, from 36 percent to 60 percent. However, the bulk of this increase occurred over the period between 1989 and 1993. The share of the ASEAN-4 also increased over the period, with the change being more substantial in the earlier part of the period than the latter.

To summarize the evidence from the U.S. data, over the period 1993 to 1996, there is substantial stability in market shares among the three Asian groups, both at the aggregate level and at the level of individual industries. The period 1989 to 1993 shows somewhat greater changes in market shares, with Greater China advancing at the expense of the NIEs.

\section{Competition in Other Markets}

We also considered the extent to which there were changes in market shares in Japan and important European markets. As shown in Table 6, Greater China's share of the Japanese market increased in the earlier period at the expense of the NIEs, while the ASEAN-4 share was essentially constant. In the latter period, Greater's China's share continues to increase, but the bulk of this comes from a decline in Indonesia's share. In selected European markets shown in Table 7, the evidence once again suggests that (1) there was greater export-competition in the period 1989 to 1993 than in the period since 1993, and (2) Greater China's gains have come at the expense of the NIEs rather than at the expense of the ASEAN-4. (The Italian market is an exception to this characterization of the evidence.)

\section{B. Controlling for Common Factors}

In this sub-section, we go beyond the graphical evidence of Figure 3 in two respects. First, while that figure was based on nominal export growth, the analysis here is based on real export growth. Second, and more important, we look at the relationship between Chinese real export growth and real export growth in other Asian economies after controlling for the effects of common factors. Our goal is to see if in contrast 
to the visual impression given by Figure 3, the correlation between China's export growth and export growth in other Asian countries is actually negative once we have controlled for the most important proximate determinants of Asian real export growth. ${ }^{16}$ Our basic finding is that the correlation either remains significantly positive or is reduced to zero; this is no evidence of the correlation turning significantly negative.

To control for common factors, we estimate regressions of real export growth in a particular Asian economy on its proximate determinants, namely, the growth rate of foreign output and the (percent) change in the trade-weighted real exchange rate. (An increase in the real exchange rate indicates an appreciation of the Asian currency relative to that of its trading partners.) We add Greater China's real export growth as a regressor to these standard export equations.

The data used in the estimation are annual, and extend from 1973 to 1996 . To obtain sufficient degrees of freedom, we pool the data for the three NIEs, for ASEAN-4 members, and also for all seven economies. Country fixed effects are included in all regressions, but their estimates are not reported.

The results of the estimation are shown in Table 8. The first column presents the results of a regression of real export growth in the NIEs on (1) country fixed effects, (2) a lagged dependent variable and (3) Greater China's real export growth. As shown, the coefficient estimate on the last of these variables is positive, quite large in magnitude (0.58), and significantly different from zero. In the second column, the growth rate of foreign output and the change in the real exchange rate are included as regressors. The coefficient estimates of these two variables have the expected signs and, statistically, are significantly different from zero. For present purposes, the key result is that the coefficient on Chinese real export growth now drops to 0.11 , and we cannot reject the null that the correlation is zero. Adding in lags of the independent variables, as in done in column (3), does not materially affect the conclusion that the coefficient

${ }^{16}$ Supply-side influences that are in common, such as coincident expansion in export capacity in these economies, is not accounted for in these equations. 
estimate is essentially zero.

A similar set of regressions for the ASEAN-4 group is presented in columns (4) to (6). In this case, the conditional correlations are always positive, large in magnitude, and significantly different from zero. When data for all seven economies is pooled, the conditional correlations generally lie in between the correlations for the two groups, as is shown in columns (7) to (9).

\section{The Industrial Composition of Asian Exports}

So far in this section we have looked at the historical relationship between Greater China's and the rest of Asia's exports. We conclude by asking: Is the historical relationship indicative of how much competition there might be in the future? One way of trying to answer this question is to compare the current (i.e. 1997) industrial composition of China's exports with that of other Asian economies.

We have carried out this analysis with BEA data for the U.S. data since we have a fairly disaggregated breakdown of exports in this case. Preliminary analysis revealed that for almost all countries, the bulk of exports are accounted for by two product clusters, (1) semiconductors and some related capital goods (industries 200 to 216) and (2) apparel, footwear and household goods (industries 400 to 420 ). For convenience, we will refer to these clusters as "industry 2 " and "industry $4, "$ respectively.

The shares of these two clusters in total exports of Asian countries to the U.S. are shown in Table 9. While the share of industry 2 in Greater China's exports has grown over time, it still accounts for less than 20 percent of its total exports. For all other countries with the exception of Indonesia, industry 2 is a more important component of their export baskets; the outlier is Singapore, where well over 80 percent of all exports are accounted for by industry 2 .

Industry 4 is clearly the dominant source of Greater China's exports to the U.S. market; though its importance has diminished since 1993, it accounts for 70 percent of exports. This industry is also still fairly important for the ASEAN-4 and for Taiwan, accounting for 30 percent to 50 percent of their exports; its 
importance to Korea and Singapore has diminished quite substantially over time.

\section{The Asian Crisis and China}

How is China likely to be affected by the 1997 Asian crisis? The first part of this section briefly reviews possible channels of contagion, through which negative shocks to one country can spread to other countries. We do not focus this review on China per se. However, we use this review in the second part of this section to discuss China's vulnerability to the Asian crisis. We highlight the role of reduced exports and capital inflows in slowing China's economy. We also argue that slowing capital inflows, as well as slowing growth generally, makes economic restructuring more difficult for China.

\section{A. Contagion Considered}

Even without any transmission of shocks across countries, multiple countries may be susceptible to a crisis if global shocks affect many countries at the same time. In Asia, three shocks seem particularly noteworthy: (1) moderating growth in industrial countries, (2) collapsing world prices for electronic goods in 1995, and (3) weakening of the yen relative to the dollar between mid-1995 and 1997 (a depreciation of about 50 percent over this time period). With their currencies pegged to the dollar, the movements in the yen led to a real appreciation of their currencies. Although these shocks did not, in and of themselves, appear to provoke widespread problems, they may have left many economies vulnerable, thereby making transmission of crisis easier.

But once an adverse shock hits one country, how might it be transmitted to other countries? Various (possibly interrelated) channels have been proposed, including:

- Trade linkages. There is both a price and an income effect. As a concrete example, consider events in Korea in late 1997, when the won depreciated sharply and growth slowed. The won's depreciation affected the current and prospective international competitiveness of other countries - China, for example, became less competitive relative to Korea. Second, lower income growth in Korea reduces growth in Korean demand for imports, including imports from China. 
- Reassessment of Fundamentals. Investors may reinterpret or downgrade the information that they have at hand, even if no new information is available. Nervous foreign investors may focus particularly on economies with policies and conditions similar to those of "crisis" economies, even if they did not see those policies and conditions as major risk factors before. For example, events in Thailand and Indonesia in mid-1997 highlighted the dangers of financial sector weaknesses, so investors may have paid closer attention to other countries with weak financial sectors, such as Korea. (Of course, fundamentals may in fact change following the crisis. For example, the change in demand for a country's net exports intrinsically represents a change in fundamentals, which may therefore merit a reassessment.)

- Perceptions of risk. Following a negative shock to one market, investors may require a larger risk premium in other markets. This increased risk premium may reflect an increase in volatility in the region generally, which raises uncertainty. One reason uncertainty might rise is if investors fear that other investors will withdraw funds, and perhaps spark a currency crisis (as discussed in the next bullet point). Risk premia may also rise because of principal-agent incentives in the financial services industry ${ }^{17}$; for example, investors might expect diligent fund managers to reduce exposure to South Korea and other Asian economies after the crisis began.

- Speculators. Speculators can hasten the demise of a currency following changes in any of the factors above-relative prices, assessments of fundamentals, or perceptions of risk. To a large extent, this process simply accelerates adjustments that needs to be made in any case. But in addition, speculation may reflect a rational, self-fulfilling crisis of confidence, akin to a bank run. For example, a pegged rate may be sustainable if speculators do not attack; but once speculators attack the currency, policymakers abandon the peg rather than bear the cost of the high real interest rates necessary to sustain it. (A large literature explores when such self-fulfilling currency crises are possible; see, for example, Obstfeld (1996) and Krugman (1997).)

- Proxy hedging or proxy disinvestment. Many financial markets lack the depth to hedge risks appropriately. However, investors may be able to take a large hedging position using an asset (the "proxy") with which its movements are likely to be correlated. For example, investors might short the Hong Kong dollar as a way to hedge exposure to the Chinese renminbi. (In other words, you cannot easily speculate against the renminbi directly - but if you think that China's exchange rate regime is unsustainable, you may speculate against the Hong Kong dollar and Hong Kong dollar assets, even if you think the fundamentals in Hong Kong are otherwise relatively strong.)

\section{B. Will China catch the Asian Flu?}

Despite the existence of these numerous channels, China has not-as of March 1998-been greatly affected by the region's current financial crisis, with the currency remaining stable against the dollar and foreign-exchange reserves increasing. Output growth slowed in the second half of 1997 to only about 8

${ }^{17}$ Dow and Gorton (1997) provide one such model. 
percent year-over-year (compared with average annual growth of more than 11 percent between 1991 and 1996), but most observers attributed the slowdown to domestic rather than external economic developments. In part, the relative immunity reflects the lack of convertibility of China's currency, which makes a speculative attack difficult, eliminating one major channel of transmission discussed above.

Several other features of China's economy are also noteworthy: China has a large current account surplus, large foreign-exchange reserves, a relatively low ratio of debt-to-GDP, and relatively little portfolio investment. These features tend to weaken some of the channels of contagion described above. However, several channels do remain at work, including trade linkages, reassessments of fundamentals, and perceptions of risk. Hence, to the extent speculation simply accelerates adjustments to changes in fundamentals or perceptions, the lack of capital account convertibility suggest that China's adjustments will be slower but that China will feel the effects of the crisis.

The primary mechanisms for these channels to affect China is through reduced exports, and reduced capital inflows. Consider exports first. Between June 1997 and early February 1998, exchange rates for all major Asian currencies other than those of China and Hong Kong depreciated against the U.S. dollar, by moderate amounts (around 20 percent) in Taiwan and Singapore, and larger amounts (between 40 and 75 percent) elsewhere. Although inflation has edged up in all of these economies, it appears unlikely that the real depreciations will reverse in the near term (in part because there has been a substantial decline in the relative price of non-tradeables and tradeables, and this relative-price change is likely to remain). The real depreciations of Asian (especially ASEAN-4) currencies hurts China's export prospects by increasing the competitiveness of these economies exports. The effects through the income channel (working through the weakness of Asian economies, including Japan) have not been fully played out, but also work in the direction of weakening China's exports.

To the extent that China produces different goods than other Asian economies, it is less sensitive to the depreciations of other Asian economies. In addition, more than half of China's export volume (56 
percent in 1996) ${ }^{18}$ involves processing trade, in which China imports partially assembled goods, and completes labor-intensive assembly. The relative appreciation of the renminbi reduces the renminbi-cost of these imported components, partially offsetting the competitive effects of the Asian crisis. However, the Asian depreciations reduce the incentives to locate labor-intensive assembly in China, so at the margin, export growth will slow. In addition, the changes in relative prices can also lead to a shift away from goods in which China has a comparative advantage, and goods where other Asian economies have a comparative advantage.

Now consider capital inflows. A likely reason for inflows to slow is that the Asian crisis has already caused investors to increase their China risk premium. The top panel of Figure 6 shows the widening of the yield spread between Chinese sovereign debt and U.S. Treasuries, using a dollar-denominated Chinese government bond due in February 2004. The yield spread, which averaged about 75 basis points until early September 1997, had risen to about 150 basis points by early January. (In late February, the spread narrowed slightly to about 130 basis points, and remained there into early March.)

Even more striking is the offshore renminbi forward exchange rate, shown in the bottom left panel. (There is no formal forward market for renminbi in China, but there is an offshore non-deliverable-forward market, where all contracting and delivery is done in foreign currency, but based on the value of the renminbi.) The bottom right panel translates these forward exchange rates into offshore interest differentials relative to U.S. dollar interest rates, using the covered-interest-parity condition. The forward rate remained relatively stable until late October; when the Hong Kong dollar came under speculative pressure on October 24 , the renminbi forward rate also spiked upwards, and the interest-rate differential rose to more than 20 percent.

The forward rate primarily reflects exchange-rate risk, and incorporates both expectations about the expected future spot rate, and a currency risk premium. The risk premium is likely to be particularly important, since the main participants in the market are probably investors who have a large renminbi

${ }^{18}$ From "Foreign Trade Approaches $\$ 300$ billion in 1996, " Zhonguo Xinwen She, January 10, 1997, reported as FBIS-CHI-97-007. 
exposure over the next year, and are willing to pay a sizeable premium to insure against the possibility of a large devaluation. Whether it reflects a change in exchange rate expectations or a change in the risk premium, the forward rate suggests a substantial shift in perceptions by financial market participants. (For comparison, as of early February 1998, Consensus Estimates (1998) forecast an expected renminbi depreciation of about 1 percent over the next year; if the forward rate were an unbiased estimate of the future spot rate, the forward rate of about 9 renminbi/dollar implies roughly a 10-percent depreciation over the next year.)

A higher risk premium is likely to show up in reduced capital inflows. Of course, more than 85 percent of China's capital inflows take the form of foreign direct investment (FDI) ${ }^{19}$-amounting to $\$ 38$ billion in 1995, $\$ 42$ billion in 1996, and $\$ 45$ billion in 1997 - which is usually presumed to be less subject to reversal than other forms of capital inflows. ${ }^{20}$ Nevertheless, even if FDI does not reverse (with investors dismantling a factory and shipping it to, say, Korea), the level of inflows can fall substantially. Indeed, the value of new contracts signed for FDI fell sharply in 1997 from 1996 (down 29 percent); although the relationship between China's contracted FDI and actual future inflows is not clear, the figures already suggest a likely slowdown. The slowdown in contracted FDI appeared in the first half of 1997, even before the Asian crisis. The crisis in the second half of 1997 only makes things worse.

Even apart from the evidence on contracted FDI, there are at least two reasons to expect the Asian crisis to contribute to a sharp decline in actual FDI. First, more than 80 percent of Chinese FDI comes from other Asian economies, and investors from many of these economies are in no position to continue rapid investment into China. For example, between 1992 and 1995, Hong Kong accounted for about 60 percent of FDI, Taiwan 10 percent, and Japan 7 percent. (The United States, by comparison, accounted for a little

${ }^{19}$ Figures from "China: Joint-Stock System Development in Perspective," FBIS-CHI-98-022, January 22, 1998. See also China Statistical Yearbook (1996), Table 16-15, p. 598.

${ }^{20}$ Anecdotal evidence suggests that some of China's FDI may be disguised lending. First, some FDI contracts specify fixed dividends that look a lot like interest payments. Second, Chinese firms sometimes circumvent the severe restrictions on foreign borrowing by establishing subsidiaries in Hong Kong, who borrow from international markets and then undertake FDI in China. Conceptually, both of these examples are closer to being debt than to being FDI. 
over 7 percent). In recent years, investors from other Asian economies have also been investing increasing amounts in China: In 1995, for example, the ASEAN-4 economies, plus Korea, accounted for about \$2 billion in FDI (5 percent of the total), and Singapore accounted for an additional \$2 billion. ${ }^{21} 22$

Second, even Western firms that undertake FDI in China may well reduce investments. If firms invest as an export platform, other Asian economies now appear more competitive. If firms invest in order to get access to China's domestic market, a possible slowdown in China makes that less enticing. Finally, firms may perceive Asia generally as a less desirable place to invest and produce, consistent with a higher regional risk premium.

Finally, one implication of a slowdown of capital inflows is that it makes enterprise restructuring more difficult. In 1997, China announced plans to restructure state-owned enterprises (SOEs) and reduce their role in the economy. This major shift requires a massive reallocation of labor and capital, which in turn requires substantial investments in new firms. But FDI is a major source of financing for the non-state sector, so any decline in FDI is likely to make this reallocation more difficult. In other words, downsizing SOEs requires destroying existing jobs and laying off workers, a politically difficult step. This downsizing is easier if new jobs are being created, and the pace of job creation is likely to slow because of reductions in the financing available to the non-state sector.

Unemployment is already a concern of Chinese policymakers, and press commentary already suggests concerns about social stability. The official urban unemployment rate was only 4 percent at the end of September 1997, but is misleadingly low for at least two reasons. First, it excludes workers who have

${ }^{21}$ Data in this paragraph are from China Statistical Yearbook, various years.

${ }^{22}$ The ultimate sources of financing for Hong Kong FDI into China remains unclear. One source is Chinese money, illegally diverted to Hong Kong and then repatriated in order to take advantage of foreign investment incentives. In addition, Chan and Chow (1997) report that in a sample of audited Chinese joint ventures, only about half of Hong-Kong-incorporated enterprises were owned primarily by Hong Kong residents: Many multinationals invest in China through Hong Kong subsidiaries, and smaller Western investors often form joint ventures with Hong Kong firms in order to benefit from their Chinese expertise; many Taiwan residents invest in China through Hong Kong for political reasons. In addition, much of the ultimate funding for FDI may take the form of borrowing (e.g., from Japanese banks) by Hong Kong firms, who then undertake FDI. If this bank lending dries up, as seems likely, Hong Kong investment will also decline. 
been sent home on partial pay. Second, it includes only official urban residents (29 percent of the population); hence, it does not include the presumably substantial unemployment among the "floating population" of generally unskilled rural workers who have moved to the cities in search of jobs. At least 30 million surplus rural workers (estimates range as high as 110 million, or 9 percent of the population) have moved to urban areas but do not have official residency status.

The main argument for continued enterprise and banking reforms is that without them, growth will slow over time and perhaps stagnate. However, radical reforms are costly in the short run, and could easily generate a sharp contraction. Enterprise restructuring of the sort discussed following China's 15 th Party Congress represent a substantial restructuring of the economy. Restructuring was enormously costly in terms of output in Eastern Europe and the former Soviet Union. One can argue about whether China is, or is not, similar to those countries. But even for industrial countries, there is a substantial body of macroeconomic literature that explores the importance of sectoral shifts, suggesting that reallocations are costly in the shortterm. The controversy in this literature is not whether reallocations/restructuring are costly in principle, but whether they are important in practice (they might not turn out to be a significant source of shocks to the United States, say). So macroeconomic literature suggests that a contraction is likely in the short term, should China attempt radical restructuring.

A concern is that Chinese leaders may find the political risks of a short-term contraction greater than the risks from a long-term slowdown in growth. The Asian crisis may raise the short-term risks, because China already faces a possible slowdown in the next year or so.

How much of a short-term risk do China's financial market weaknesses pose to China? After Thailand's currency crisis erupted in mid-summer 1997, it became clear to many investors that they had underestimated the risks associated with weak financial systems, contributing to a reassessment of other Asian developing economies. Some commentators argue that China's financial system looks at least as bad, and perhaps far worse, than those of other regional economies. ${ }^{23}$ Most notably, China's banking system has

${ }^{23}$ See, for example, Nicholas Cashmore, "Work in Progress," Asiamoney June 1997, p 51-55; and George Melloan, "The Stakes Are Rising on China's Banking Reforms," Wall Street Journal July 14, 1997, p. A15. 
an enormous overhang of bad loans. In January 1998, for example, People's Bank of China Governor Dai stated that more than 20 percent of bank loans are nonperforming, although he argued that only 5 to 6 percent of loans are unrecoverable; but Western observers generally estimate that the proportion of non-performing and unrecoverable loans may be far higher. ${ }^{24}$

In most Asian economies, policymakers' post-crisis concern with banking-sector health generally reflects both short- and long-term concerns. In the short-term, poor bank health can lead to a "credit crunch," as banks reduce lending even to viable non-financial firms, thus exacerbating the real effects of the crisis. For example, banks may lose the funding base (deposits) with which to make loans; and even if they have the funding, they may not have adequate capital to make loans.

This short-term concern is probably not relevant to China. In particular, if China's bank loans go bad, or are recognized as bad, they will not have the same impact on the lending behavior of the banks as would occur elsewhere. In particular, it is unlikely that in order to restore their "profitability," Chinese banks will be forced to cut back on other loans. First, it is fairly clear that the Chinese government continues to guarantee bank deposits-which are, after all, primarily held in state banks. Hence, depositors continue to have faith in the banking system. Second, if a severe credit crunch begins to impinge on the real economy, Chinese authorities can in essence order the banks to lend. In other words, despite substantial moves in recent years to make the banking system more competitive and commercially oriented, neither the Chinese authorities nor anyone else believes the banking system is fully commercially oriented, or operates independent of the government. The problems of China's banking system are primarily a fiscal issue, and as long as government guarantees are credible, the financial sector weaknesses are unlikely to lead to a shortterm credit crunch.

Nevertheless, despite the fact that banking system weakness is unlikely to result in an immediate credit-crunch, one short-term risk is that a slowdown in output and increases in bankruptcies might cause some of banks to become illiquid, when interest income cannot cover normal deposit withdrawals. Alternatively, if depositors decide to increase their withdrawals-perhaps because they lose faith in the

${ }^{24}$ See, for example, Roell (1997). 
banking system, or perhaps because they simply decide to reduce their (currently large) holdings of broad money-banks may find themselves illiquid. If the government is then forced to rescue the banks, the most accessible source of funding is the central bank. Then the government may face the undesirable choice of seeing an increase in inflation, or a substantial slowdown in growth.

In the long-term, China's financial market weaknesses raise severe concerns about whether resources are channeled to their most productive uses. Because of these long-term concerns, Chinese policymakers hope to continue progress on removing the need to make policy loans (through enterprise reform), in providing banks with experience and skill in assessing loans on commercial grounds, and in improving the transparency and accountability of banks. These are necessary steps before Chinese policymakers can successfully recapitalize the banks or otherwise try to solve the underlying problems of inherited bad loans of the banking system.

For example, even if China's banks were financially sound and healthy, recapitalization would not resolve the inherent incentive problems of the banks. The savings and loan problem in the United States highlighted the moral hazard problems facing financial institutions with low net worth, but access to deposit insurance. In the United States, there were clear incentives for the owners of these institutions to engage in risky behavior; if they were more solvent, the owners would not have faced these incentives. For Chinese banks, however, the issue is the incentives faced by bank managers (rather than owners). Managers may continue to have incentives to make loans to friends or powerful politicians, for example.

An important lesson of the Asian financial crisis is that weaknesses in financial markets, and moralhazard incentives facing bankers, can have devastating effects on an economy. Chinese policymakers appear aware of these dangers. It is noteworthy, and favorable, that in early 1998, policymakers announced numerous plans to accelerate financial market reforms, explicitly citing a desire to try avoiding an Asianstyle crisis. Policies included central bank reforms, in order to improve local supervision, and bank reforms that seek to improve the ability of banks to operate on commercial grounds, with greater independence from government-directed quotas. 


\section{Conclusions}

Motivated by the 1997 financial crisis in Asia, this paper explores the links between China and the rest of Asia. Surprisingly, we find no evidence that China's export growth had a negative effect on exports of other emerging Asian economies. To the extent there is evidence of export competition, it is the period from about 1989 to 1993: China's exchange rate depreciated sharply over this period, Chinese export growth exceeded export growth of other Asian economies, and the composition of Asian exports (measured by export shares of various goods to the United States and other industrial economies) changed substantially. Since 1993, by contrast, China's exchange rate has appreciated, China's export growth has been strikingly similar to that of other Asian economies, and the composition of exports has been relatively stable.

Thus, it does not appear that China's emergence as a trading nation had a significant adverse effect on the rest of Asia's export performance. In recent years, Asian trade performance appears to have been driven primarily by factors common to all Asian economies, including China. In 1997, however, China's trade performance has far exceeded that of other Asian economies.

Finally, we speculate on the effect of the Asian crisis on China. Because of the large real depreciations of many Asian currencies, China will face more trade competition, and will face reduced demand for its exports, reflecting the slowdown in Asia. China is also likely to face a slowdown in capital inflows, which will lead to reduced domestic investment. This reduction in inflows will make stateenterprise reform more difficult, by reducing growth and job-creation in the non-state sector. Thus, although China has remained insulated from the crisis so far, it appears susceptible in the future. 


\section{Bibliography}

Ahmed, Shaghil and Prakash Loungani (1997). "Business Cycles in Asia." Manuscript, Federal Reserve Board.

Bell, Michael W., Hoe Ee Khor, and Kalpana Kochhar (1993). "China at the Threshold of a Market Economy." International Monetary Fund Occasional Paper 107.

C. Fred Bergsten (1997). "The Asian Monetary Crisis: Proposed Remedies," prepared remarks to the U.S. House of Representatives Committee on Banking and Financial Services, November 13.

Chan, K. Hung and Lynne Chow (1997). "An empirical study of tax audits in China on international transfer pricing." Journal of Accounting and Economics 23 (1997): 83-112.

Dow, James and Gary Gorton (1997). "Noise Trading, Delegated Portfolio Management, and Economic Welfare." Journal of Political Economy, 105 (October): 1024-1050.

Feenstra, Robert C., Wen Hai, Wing T. Woo, Jeffrey Sachs, and Shunli Yao (1998). "The U.S.-China Bilateral Trade Balance: Its Size and Determinants." Manuscript prepared for the UNDP-HIID Conference on China's Integration into the Global Economy, January.

Fung, K.C. (1996). "Accounting for Chinese Trade: Some National and Regional Considerations." NBER Working Paper No. 5595.

Hong Kong Census and Statistics Bureau, Annual Review of Hong Kong External Trade.

Huh, Chan and Kenneth Kasa (1997). "A Dynamic Model of Export Competition, Policy Coordination, and Simultaneous Currency Collapse." Manuscript, Center for Pacific Basin Monetary and Economic Studies, Economic Research Department, Federal Reserve Bank of San Francisco WP PB97-08.

Khor, Hoe Ee (1993). "China's Foreign Currency Swap Market." IMF Paper on Policy Analysis and Assessment PPAA/94/1. December.

Krugman, Paul (1997a). "The East is in the Red: A Balanced View of China's Trade." Slate Magazine, July 17.

Krugman, Paul (1997b). "Currency Crises." Manuscript prepared for NBER conference, October 1997. (Obtained from http:/web.mit.edu/krugman/www/crises.html.)

Lardy, Nicholas (1994). China and the World Economy.

Liu, Ligang, Marcus Noland, Sherman Robinson, and Zhi Wang (1998). "Asian Competitive Devaluations." Manuscript prepared for the UNDP-HIID Conference on China's Integration into the Global Economy, January.

John H. Makin (1997), "Two New Paradigms." American Enterprise Institute, (October) . 
Melick, Will (1997). "Competitive Devaluations." Memo.

Mehran, Hassanali, Marc Quintyn, Tom Nordman, and Bernard Laurens (1996). "Monetary and Exchange System Reforms in China: An Experiment in Gradualism," IMF Occasional Paper 141.

Roell, Sophie (1997). "It's Your Move, Mr. Zhu." Euromoney, February 1997, pp52-56.

Tseng, Wanda, Hoe Ee Khor, Kalpana Kochhar, Dubravko Mihaljek, and David Burton (1994). "Economic Reform in China: A New Phase." International Monetary Fund Occasional Paper 114.

World Bank (1993). China Updating Economic Memorandum: Managing Rapid Growth and Transition. 
Table 1

Exports of and Imports from Greater China (1996, US\$ billions)

\begin{tabular}{|c|c|c|c|c|c|c|}
\hline \multirow{3}{*}{$\begin{array}{l}\text { Destination: } \\
\text { World Imports of and Exports to: }\end{array}$} & \multicolumn{3}{|c|}{ Exports of (origin): } & \multicolumn{3}{|c|}{ Imports from(origin): } \\
\hline & China & $\begin{array}{l}\text { Hong } \\
\text { Kong } \\
\end{array}$ & $\begin{array}{c}\text { Greater } \\
\text { China } \\
\end{array}$ & China & Hong Kong & $\begin{array}{c}\text { Greater } \\
\text { China }\end{array}$ \\
\hline & (1) & (2) & (3) & (1a) & $(2 a)$ & (3a) \\
\hline 1. United States & 27 & 38 & 65 & 54 & 10 & 65 \\
\hline 2. Japan & 31 & 12 & 43 & 40 & 3 & 43 \\
\hline 3. Other Industrial & 24 & 34 & 58 & 44 & 18 & 62 \\
\hline 4. Total Industrial & 82 & 84 & 166 & 139 & 30 & 170 \\
\hline 5. Korea, Sing., Taiwan (NIEs) & 14 & 12 & 26 & 13 & 5 & 18 \\
\hline 6. Indon., Thai., Malay., Philipp. & 5 & 7 & 12 & 6 & 5 & 11 \\
\hline 7. Other Asia, excl. Hong Kong & 4 & 4 & 9 & 8 & 6 & 13 \\
\hline 8. Other & 13 & 12 & 24 & 15 & 5 & 20 \\
\hline 9. Total - excl. trade between China and HK & 118 & 119 & 237 & 181 & 51 & 232 \\
\hline 10. Trade between Hong Kong and China & 33 & 62 & 95 & 74 & 8 & 82 \\
\hline 11. memo: World Total & 151 & 181 & 332 & 255 & 59 & 314 \\
\hline
\end{tabular}

Note: Columns (1)-(3) show China and Hong Kong's reported exports to the regions shown. Columns (1a)-(3c) show trading partner imports from China and Hong Kong. Numbers may not add up because of rounding.

Source: IMF Direction of Trade Statistics and Taiwan statistics. 
Table 2

Imports of and Exports to Greater China (1996, US\$ billions)

\begin{tabular}{|c|c|c|c|c|c|c|}
\hline \multirow{3}{*}{$\begin{array}{l}\text { Origin: } \\
\text { Imports from, and exports of: }\end{array}$} & \multicolumn{3}{|c|}{ Destination (Imports of) } & \multicolumn{3}{|c|}{ Destination (Exports to) } \\
\hline & China & $\begin{array}{l}\text { Hong } \\
\text { Kong } \\
\end{array}$ & $\begin{array}{c}\text { Greater } \\
\text { China }\end{array}$ & China & Hong Kong & $\begin{array}{l}\text { Greater } \\
\text { China }\end{array}$ \\
\hline & $(1)$ & (2) & (3) & (1a) & $(2 a)$ & $(3 a)$ \\
\hline 1. United States & 16 & 16 & 32 & 12 & 14 & 26 \\
\hline 2. Japan & 29 & 27 & 56 & 22 & 25 & 47 \\
\hline 3. Other Industrial & 27 & 28 & 55 & 25 & 28 & 53 \\
\hline 4. Total Industrial & 73 & 70 & 143 & 59 & 68 & 126 \\
\hline 5. Korea, Sing., Taiwan (NIEs) & 32 & 36 & 68 & 15 & 49 & 64 \\
\hline 6. Indon., Thai., Malay., Philipp. & 7 & 10 & 17 & 6 & 10 & 16 \\
\hline 7. Other Asia, excl. Hong Kong & 2 & 3 & 5 & 2 & 4 & 6 \\
\hline 8. Other & 17 & 6 & 23 & 13 & 4 & 17 \\
\hline 9. Total - excl. trade between China and HK & 131 & 125 & 256 & 95 & 135 & 230 \\
\hline 10. Trade between Hong Kong and China & 8 & 74 & 82 & 62 & 33 & 95 \\
\hline 11. memo: World Total & 139 & 199 & 337 & 157 & 168 & 325 \\
\hline
\end{tabular}

Note: Columns (1)-(3) show China and Hong Kong's reported imports from the regions shown. Columns (1a)-(3c) show exports of the region shown to China and Hong Kong. Numbers may not add up because of rounding.

Source: IMF Direction of Trade Statistics and Taiwan statistics. 
Table 3

Greater China Trade Balance, by Region (1996, US\$ billions)

\begin{tabular}{|c|c|c|c|c|c|c|}
\hline \multirow{3}{*}{ Trading Partner } & \multicolumn{3}{|c|}{ Trade Balance of } & \multicolumn{3}{|c|}{ Trade Balance of } \\
\hline & China & $\begin{array}{l}\text { Hong } \\
\text { Kong }\end{array}$ & $\begin{array}{c}\text { Greater } \\
\text { China }\end{array}$ & China & Hong Kong & $\begin{array}{c}\text { Greater } \\
\text { China }\end{array}$ \\
\hline & $(1)$ & $(2)$ & (3) & (1a) & $(2 a)$ & $(3 a)$ \\
\hline 1. United States & 11 & 22 & 33 & 42 & -4 & 39 \\
\hline 2. Japan & 2 & -15 & -13 & 18 & -22 & -4 \\
\hline 3. Other Industrial & -3 & 6 & 3 & 19 & -10 & 9 \\
\hline 4. Total Industrial & 9 & 14 & 23 & 80 & -38 & 44 \\
\hline 5. Korea, Sing., Taiwan (NIEs) & -18 & -24 & -42 & -2 & -44 & -46 \\
\hline 6. Indon., Thai., Malay., Philipp. & -2 & -3 & -5 & 0 & -5 & -5 \\
\hline 7. Other Asia, excl. Hong Kong & 2 & 1 & 4 & 6 & 2 & 7 \\
\hline 8. Other & -4 & 6 & 1 & 2 & 1 & 3 \\
\hline $\begin{array}{l}\text { 9. Total - excl. trade between China and } \\
\text { HK }\end{array}$ & -13 & -6 & -19 & 86 & -84 & 2 \\
\hline 10. Exports to/Imports from HK or China & 25 & -12 & 13 & 12 & -25 & -13 \\
\hline 11. memo: World Total & 12 & -18 & -6 & 97 & -109 & -11 \\
\hline
\end{tabular}

Note: Columns (1)-(3) present China and Hong Kong's reported bilateral trade balances with the economies and regions shown. Columns (1a)(3c) present China and Hong Kong's bilateral trade balance, using trading partners's statistics. Calculated as the difference between Tables 1 and 2. Numbers may not add up because of rounding.

Source: IMF Direction of Trade Statistics and Taiwan statistics. 
Table 4

Export Shares of Selected Asian Countries in the U.S. Market

\begin{tabular}{||l|l|l|l||}
\hline & $(1)$ & $(2)$ & $(3)$ \\
\hline Country & 1989 & 1993 & 1996 \\
\hline $\begin{array}{l}\text { Greater } \\
\text { China }\end{array}$ & $\mathbf{2 4}$ & $\mathbf{3 3}$ & $\mathbf{3 4}$ \\
\hline China & 13 & 25 & 29 \\
\hline HK & 11 & 8 & 5 \\
\hline NIEs & $\mathbf{5 9}$ & $\mathbf{4 4}$ & $\mathbf{4 1}$ \\
\hline Korea & 22 & 14 & 13 \\
\hline Singapore & 10 & 10 & 11 \\
\hline Taiwan & 27 & 20 & 17 \\
\hline ASEAN-4 & $\mathbf{1 7}$ & $\mathbf{2 3}$ & $\mathbf{2 5}$ \\
\hline Indonesia & 4 & 4 & 5 \\
\hline Malaysia & 5 & 8 & 10 \\
\hline Philippines & 3 & 4 & 4 \\
\hline Thailand & 5 & 7 & 6 \\
\hline $\begin{array}{l}\text { Total } \\
\text { (Greater China } \\
\text { plus NIEs + } \\
\text { ASEAN-4) }\end{array}$ & $\mathbf{1 0 0}$ & $\mathbf{1 0 0}$ & $\mathbf{1 0 0}$ \\
\hline \hline
\end{tabular}


Table 5

Export Shares of Selected Asian Countries in the U.S. Market:

Data for Two Industries

\begin{tabular}{|c|c|c|c|c|c|c|}
\hline \multirow[b]{2}{*}{ Country } & \multicolumn{3}{|c|}{$\begin{array}{l}\text { Industry } 213 \text { (computers, peripherals } \\
\text { and semiconductors) }\end{array}$} & \multicolumn{3}{|c|}{$\begin{array}{l}\text { Industry } 400 \text { (apparel, footwear and } \\
\text { household products) }\end{array}$} \\
\hline & 1989 & 1993 & 1996 & 1989 & 1993 & 1996 \\
\hline $\begin{array}{l}\text { Greater } \\
\text { China }\end{array}$ & 7 & 7 & 8 & 36 & 55 & 60 \\
\hline China & 0 & 3 & 5 & 18 & 41 & 47 \\
\hline HK & 7 & 4 & 3 & 18 & 14 & 13 \\
\hline NIEs & 72 & 68 & 65 & 52 & 26 & 17 \\
\hline Korea & 21 & 16 & 18 & 27 & 13 & 7 \\
\hline Singapore & 31 & 29 & 28 & 3 & 2 & 1 \\
\hline Taiwan & 20 & 23 & 19 & 22 & 11 & 9 \\
\hline ASEAN-4 & 21 & 25 & 27 & 12 & 19 & 23 \\
\hline Indonesia & 0 & 0 & 1 & 3 & 6 & 8 \\
\hline Malaysia & 12 & 15 & 15 & 2 & 3 & 4 \\
\hline Philippines & 4 & 4 & 6 & 3 & 5 & 5 \\
\hline Thailand & 5 & 6 & 5 & 4 & 5 & 6 \\
\hline Total & 100 & 100 & 100 & 100 & 100 & 100 \\
\hline
\end{tabular}


Table 6

Export Shares of Selected Asian Countries in the Japanese Market

\begin{tabular}{||l|c|l|l||}
\hline & $(1)$ & $(2)$ & $(3)$ \\
\hline Country & 1989 & 1993 & 1996 \\
\hline $\begin{array}{l}\text { Greater } \\
\text { China }\end{array}$ & $\mathbf{2 3}$ & $\mathbf{2 9}$ & $\mathbf{3 5}$ \\
\hline China & 19 & 27 & 33 \\
\hline HK & 4 & 2 & 2 \\
\hline NIEs & $\mathbf{4 0}$ & $\mathbf{3 3}$ & $\mathbf{3 1}$ \\
\hline Korea & 20 & 15 & 13 \\
\hline Singapore & 5 & 5 & 6 \\
\hline Taiwan & 15 & 13 & 12 \\
\hline ASEAN-4 & $\mathbf{3 7}$ & $\mathbf{3 8}$ & $\mathbf{3 4}$ \\
\hline Indonesia & 19 & 16 & 12 \\
\hline Malaysia & 9 & 10 & 10 \\
\hline Philippines & 3 & 3 & 4 \\
\hline Thailand & 6 & 9 & 8 \\
\hline Total & $\mathbf{1 0 0}$ & $\mathbf{1 0 0}$ & $\mathbf{1 0 0}$ \\
\hline \hline
\end{tabular}


Table 7

Export Shares of Selected Asian Countries in European Markets

\begin{tabular}{|c|c|c|c|c|c|c|}
\hline & \multicolumn{3}{|c|}{ France } & \multicolumn{3}{|c|}{ Germany } \\
\hline Country & 1989 & 1993 & 1996 & 1989 & 1993 & 1996 \\
\hline Greater China & 31 & 38 & 39 & 36 & 40 & 40 \\
\hline NIEs & 46 & 36 & 35 & 42 & 37 & 35 \\
\hline ASEAN-4 & 23 & 26 & 26 & 22 & 23 & 25 \\
\hline \multirow[t]{2}{*}{ Total } & 100 & 100 & 100 & 100 & 100 & 100 \\
\hline & \multicolumn{3}{|l|}{ Italy } & \multicolumn{3}{|c|}{ United Kingdom } \\
\hline Country & 1989 & 1993 & 1996 & 1989 & 1993 & 1996 \\
\hline Greater China & 37 & 41 & 50 & 34 & 37 & 34 \\
\hline NIEs & 43 & 31 & 26 & 45 & 36 & 36 \\
\hline ASEAN-4 & 20 & 28 & 24 & 21 & 27 & 30 \\
\hline Total & 100 & 100 & 100 & 100 & 100 & 100 \\
\hline
\end{tabular}


Table 8

Conditional Correlations between Greater China's Real Export Growth and Real Export Growth in other Asian Countries

\begin{tabular}{|c|c|c|c|c|c|c|c|c|c|}
\hline \multirow[b]{2}{*}{$\begin{array}{l}\text { Independent } \\
\text { variable }\end{array}$} & \multicolumn{3}{|c|}{$\begin{array}{l}\text { NIEs (Korea, Singapore, } \\
\text { Taiwan) }\end{array}$} & \multicolumn{3}{|c|}{$\begin{array}{l}\text { ASEAN-4 (Indonesia, } \\
\text { Malaysia, Philippines, } \\
\text { Thailand) }\end{array}$} & \multicolumn{3}{|c|}{$\begin{array}{l}\text { All seven countries } \\
\text { (NIEs plus ASEAN-4) }\end{array}$} \\
\hline & (1) & (2) & (3) & (4) & (5) & (6) & (7) & (8) & (9) \\
\hline $\begin{array}{l}\text { Greater } \\
\text { China's } \\
\text { real exports }\end{array}$ & $\begin{array}{c}0.58 \\
(0.18)\end{array}$ & $\begin{array}{c}\mathbf{0 . 1 3} \\
(\mathbf{0 . 1 7})\end{array}$ & $\begin{array}{c}0.11 \\
(0.25)\end{array}$ & $\begin{array}{c}0.56 \\
(0.14)\end{array}$ & $\begin{array}{c}0.35 \\
(0.14)\end{array}$ & $\begin{array}{c}0.40 \\
(0.15)\end{array}$ & $\begin{array}{c}0.56 \\
(0.11)\end{array}$ & $\begin{array}{c}0.23 \\
(0.11)\end{array}$ & $\begin{array}{c}0.26 \\
(0.14)\end{array}$ \\
\hline Lag 1 & . & . & $\begin{array}{c}0.00 \\
(0.19) \\
\end{array}$ & . & & $\begin{array}{c}0.22 \\
(0.22) \\
\end{array}$ & . & . & $\begin{array}{c}0.12 \\
(0.15) \\
\end{array}$ \\
\hline Lag 2 & . & . & $\begin{array}{l}-0.05 \\
(0.22)\end{array}$ & . & $\cdot$ & $\begin{array}{r}0.004 \\
(0.15)\end{array}$ & . & . & $\begin{array}{l}-0.04 \\
(0.12)\end{array}$ \\
\hline $\begin{array}{l}\text { Foreign } \\
\text { demand }\end{array}$ & . & $\begin{array}{c}3.27 \\
(0.67)\end{array}$ & $\begin{array}{l}2.63 \\
(0.77)\end{array}$ & . & $\begin{array}{l}1.45 \\
(0.52)\end{array}$ & $\begin{array}{l}1.46 \\
(0.74)\end{array}$ & . & $\begin{array}{l}2.34 \\
(0.45)\end{array}$ & $\begin{array}{l}2.01 \\
(0.52)\end{array}$ \\
\hline Lag 1 & . & . & $\begin{array}{l}-1.67 \\
(0.82)\end{array}$ & . & . & $\begin{array}{l}-0.18 \\
(0.14)\end{array}$ & . & . & $\begin{array}{l}-1.05 \\
(0.57)\end{array}$ \\
\hline Lag 2 & . & . & $\begin{array}{l}-0.58 \\
(0.90)\end{array}$ & . & . & $\begin{array}{l}-0.84 \\
(0.61)\end{array}$ & . & . & $\begin{array}{l}-0.67 \\
(0.51)\end{array}$ \\
\hline $\begin{array}{l}\text { Real } \\
\text { exchange rate }\end{array}$ & . & $\begin{array}{l}-0.40 \\
(0.20)\end{array}$ & $\begin{array}{l}-0.20 \\
(0.18)\end{array}$ & r & $\begin{array}{l}-0.11 \\
(0.08) \\
\end{array}$ & $\begin{array}{l}-0.21 \\
(0.09)\end{array}$ & . & $\begin{array}{l}-0.17 \\
(0.08)\end{array}$ & $\begin{array}{l}-0.18 \\
(0.08)\end{array}$ \\
\hline Lag 1 & . & . & $\begin{array}{l}-0.08 \\
(0.15)\end{array}$ & . & . & $\begin{array}{c}0.07 \\
(0.08)\end{array}$ & . & . & $\begin{array}{c}0.01 \\
(0.07)\end{array}$ \\
\hline Lag 2 & . & . & $\begin{array}{l}-0.04 \\
(0.12)\end{array}$ & . & . & $\begin{array}{c}0.14 \\
(0.12)\end{array}$ & . & . & $\begin{array}{c}0.06 \\
(0.08)\end{array}$ \\
\hline $\begin{array}{l}\text { Lagged } \\
\text { dependent } \\
\text { variable }\end{array}$ & $\begin{array}{c}0.13 \\
(0.12)\end{array}$ & $\begin{array}{c}0.04 \\
(0.11)\end{array}$ & $\begin{array}{c}0.10 \\
(0.14)\end{array}$ & $\begin{array}{c}0.09 \\
(0.09)\end{array}$ & $\begin{array}{c}0.10 \\
(0.08)\end{array}$ & $\begin{array}{c}0.08 \\
(0.11)\end{array}$ & $\begin{array}{c}0.11 \\
(0.07)\end{array}$ & $\begin{array}{c}0.07 \\
(0.06)\end{array}$ & $\begin{array}{c}0.10 \\
(0.08)\end{array}$ \\
\hline Adj. $\mathrm{R}^{2}$ & 0.11 & 0.43 & 0.36 & 0.24 & 0.29 & 0.30 & 0.21 & 0.36 & 0.35 \\
\hline
\end{tabular}


Table 9

Industrial Composition of Exports in Asian Economies

\begin{tabular}{||l|c:c:c|c:c|c||}
\hline & Industry 2 (Industries 200 to 216) & \multicolumn{2}{l||}{ Industry 4 (Industries 400 to 420) } \\
\hline Country & 1989 & 1993 & 1997 & 1989 & 1993 & 1997 \\
\hline Greater China & 13 & 13 & 19 & 72 & 75 & 69 \\
\hline Korea & 24 & 36 & 54 & 52 & 40 & 19 \\
\hline Singapore & 64 & 74 & 83 & 22 & 14 & 5 \\
\hline Taiwan & 27 & 42 & 57 & 58 & 42 & 27 \\
\hline Indonesia & 1 & 4 & 10 & 22 & 53 & 53 \\
\hline Malaysia & 46 & 51 & 61 & 34 & 38 & 28 \\
\hline Philippines & 28 & 32 & 54 & 48 & 47 & 32 \\
\hline Thailand & 22 & 28 & 37 & 45 & 44 & 39 \\
\hline
\end{tabular}


Figure 1

Official Exchange Rate and Chinese Exports
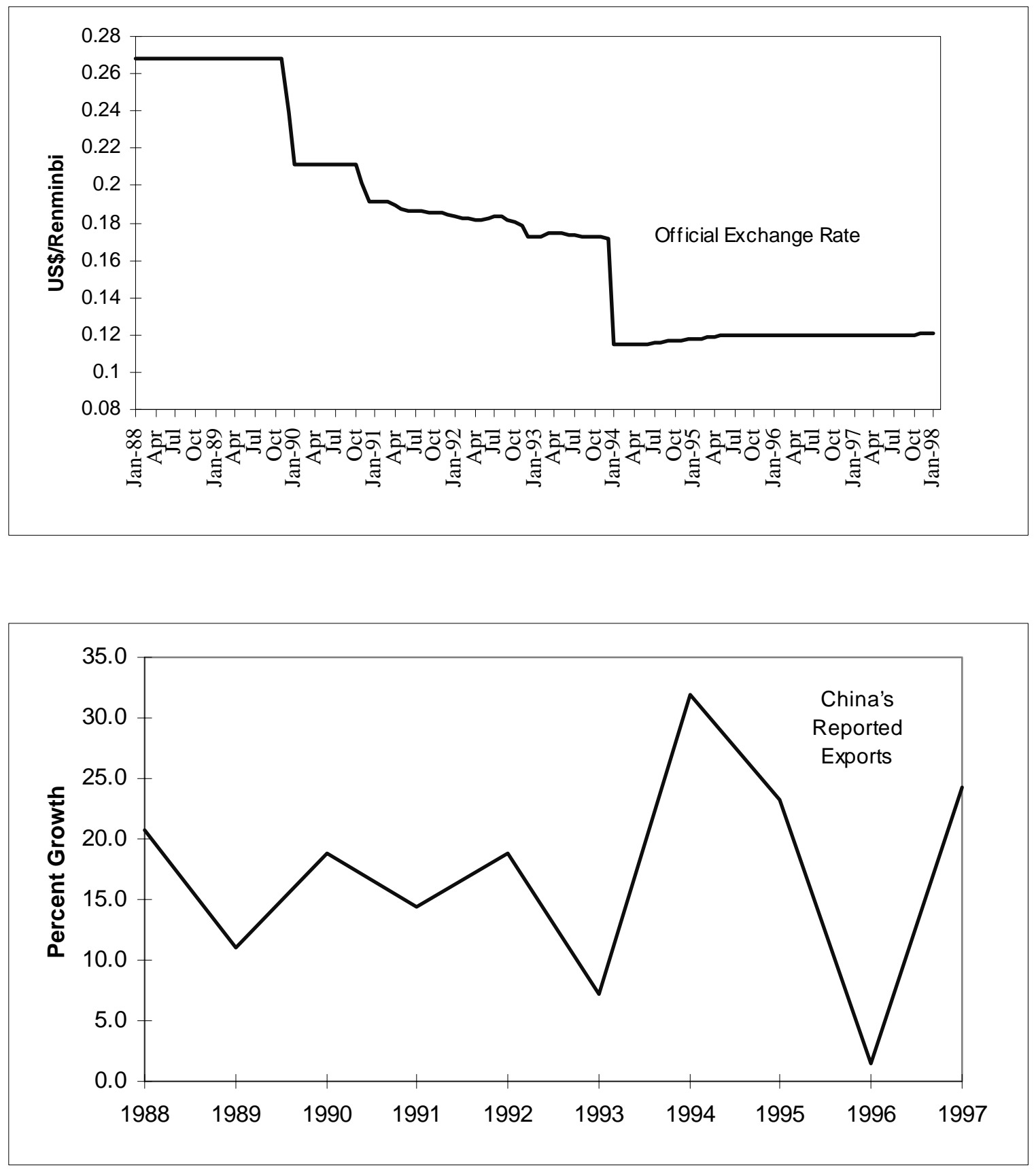
Figure 2

Alternative Nominal and Real Exchange Rates

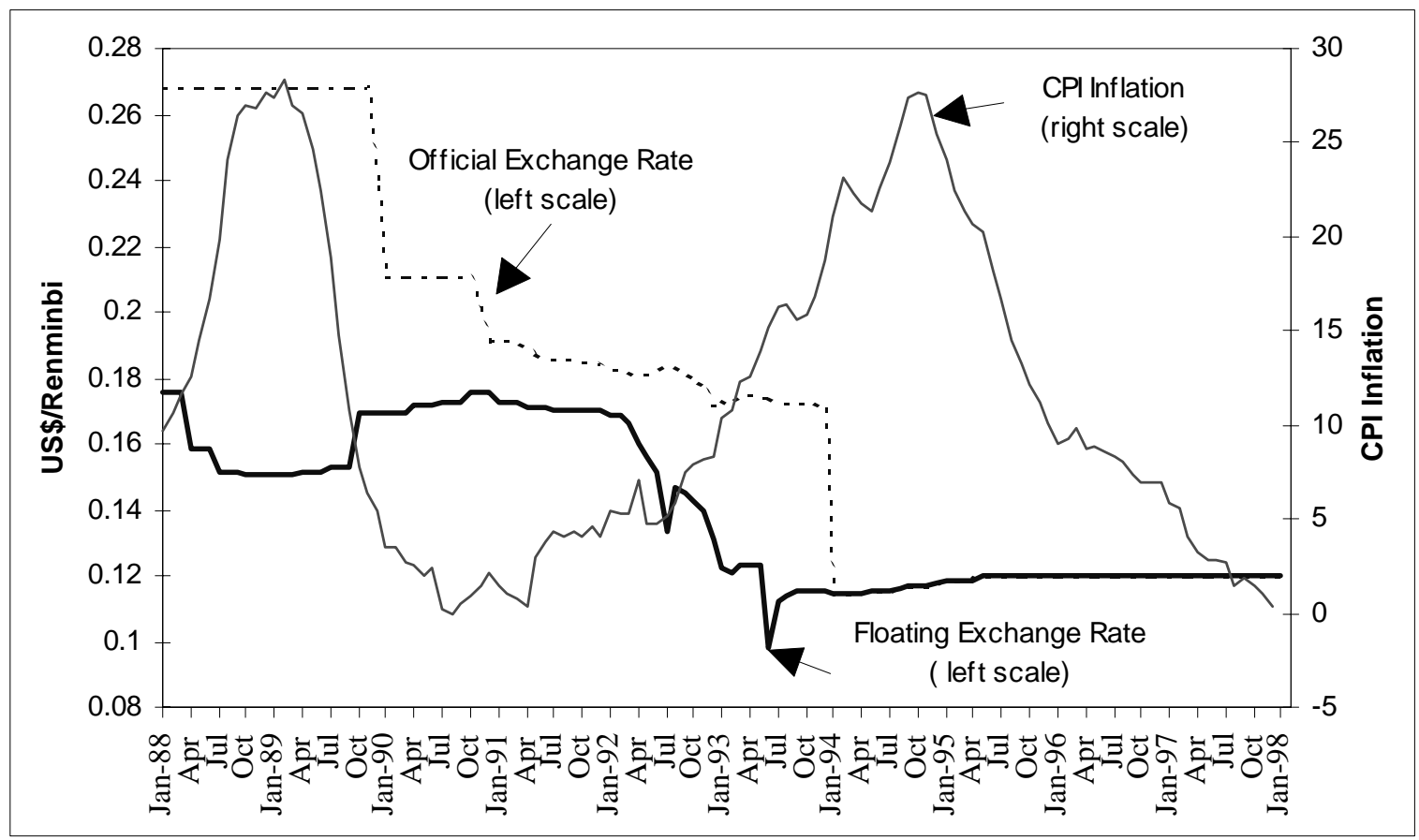

\section{Chinese Renminbi:}

Export Weighted Real Exchange Rates*

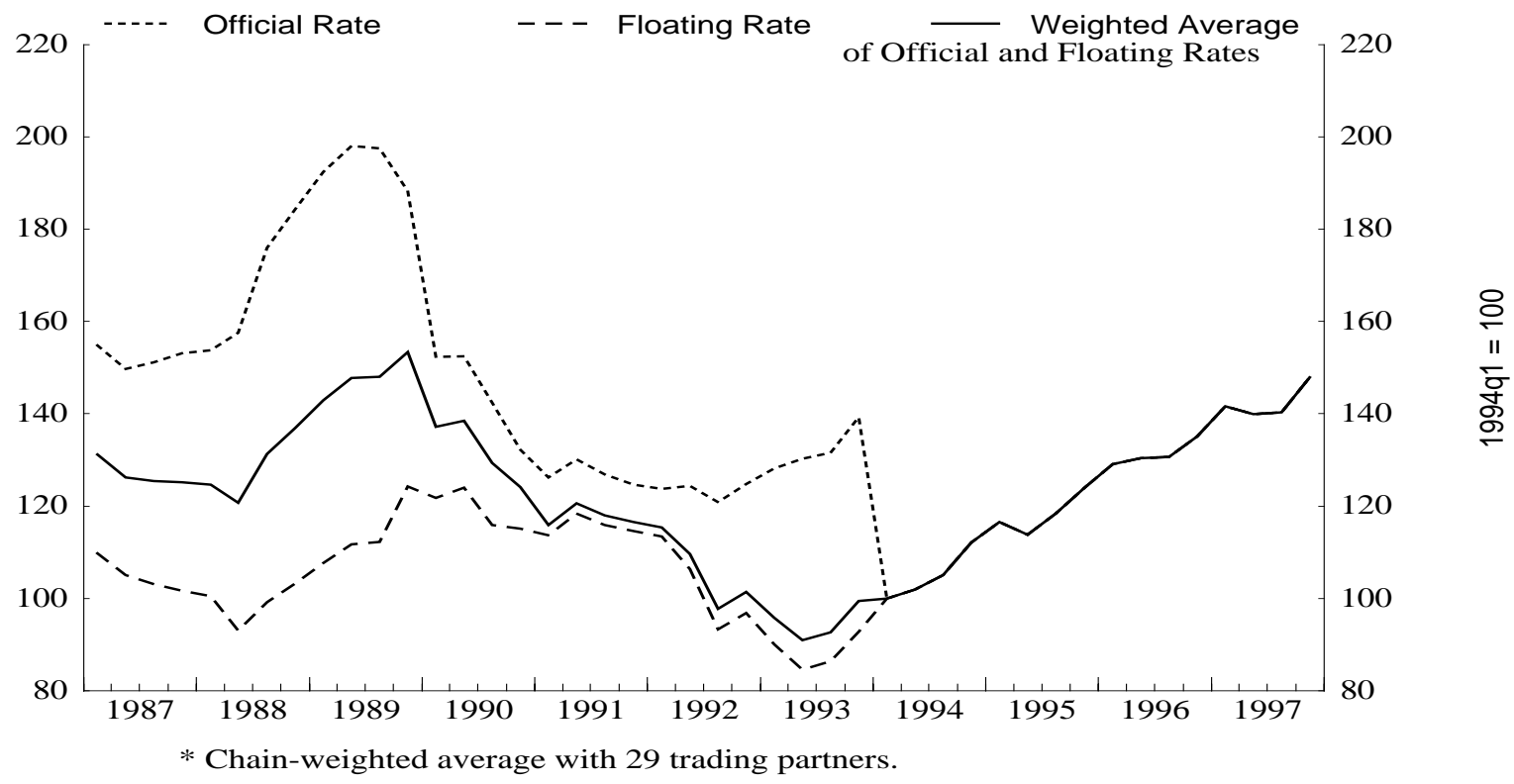


Figure 3

Export Growth of Greater China and Asia
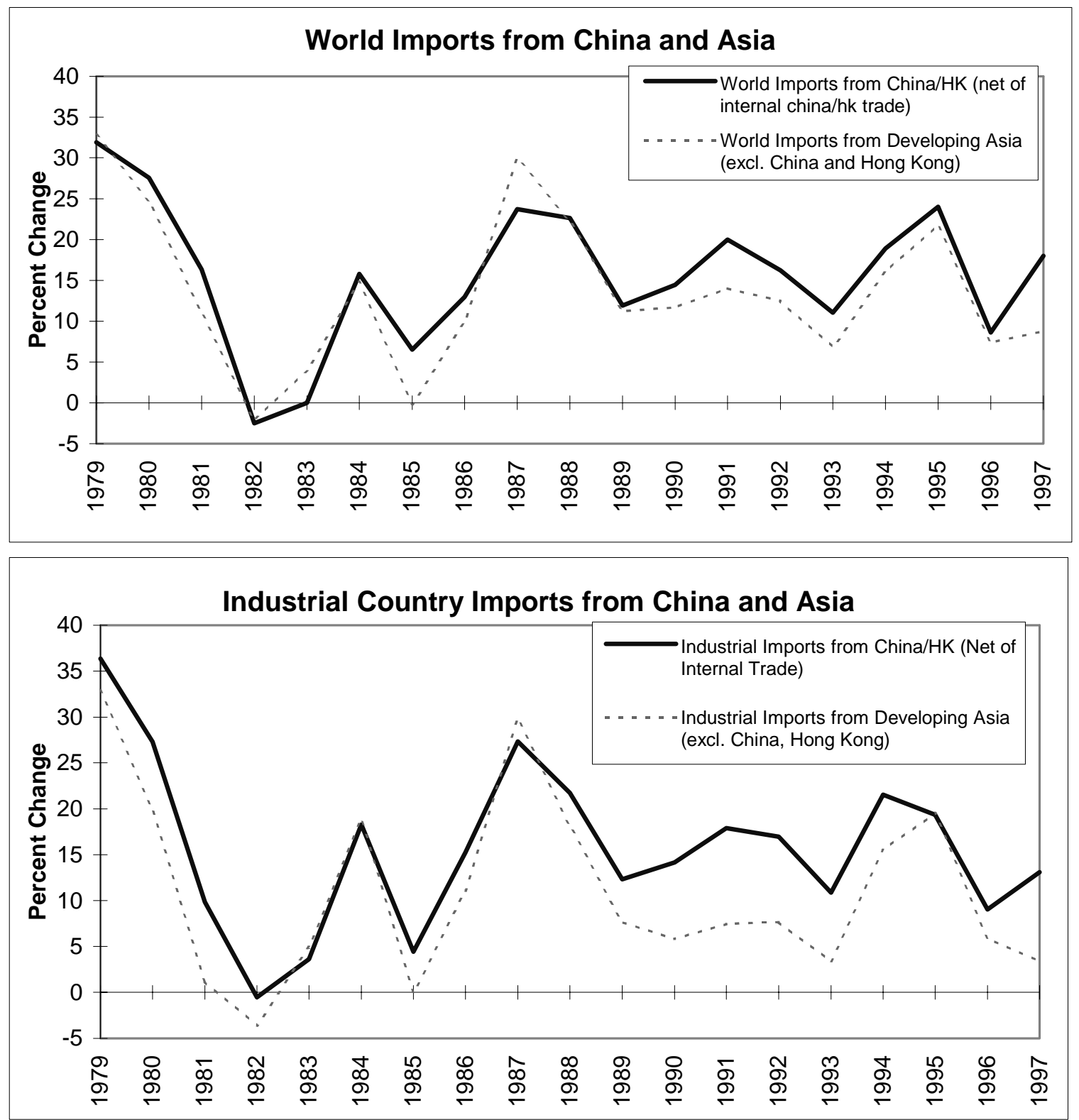

Note: Data for 1997 are through September. 
Figure 4

Export Growth by China and Hong Kong
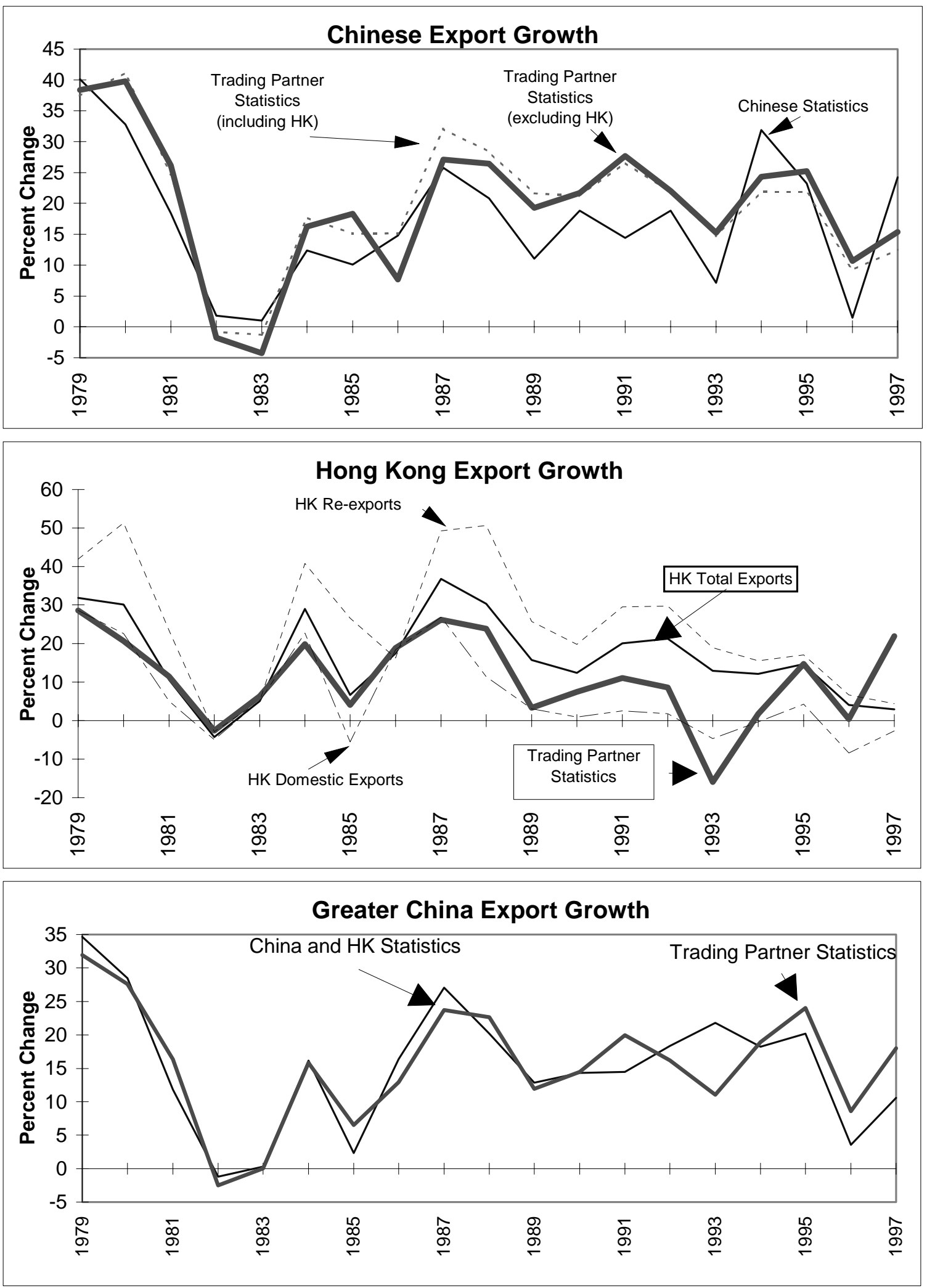

Note: Data for 1997 are through September. Source is Direction of Trade Statistics. 
Figure 5

Greater China (China plus Hong Kong) Trade Balance
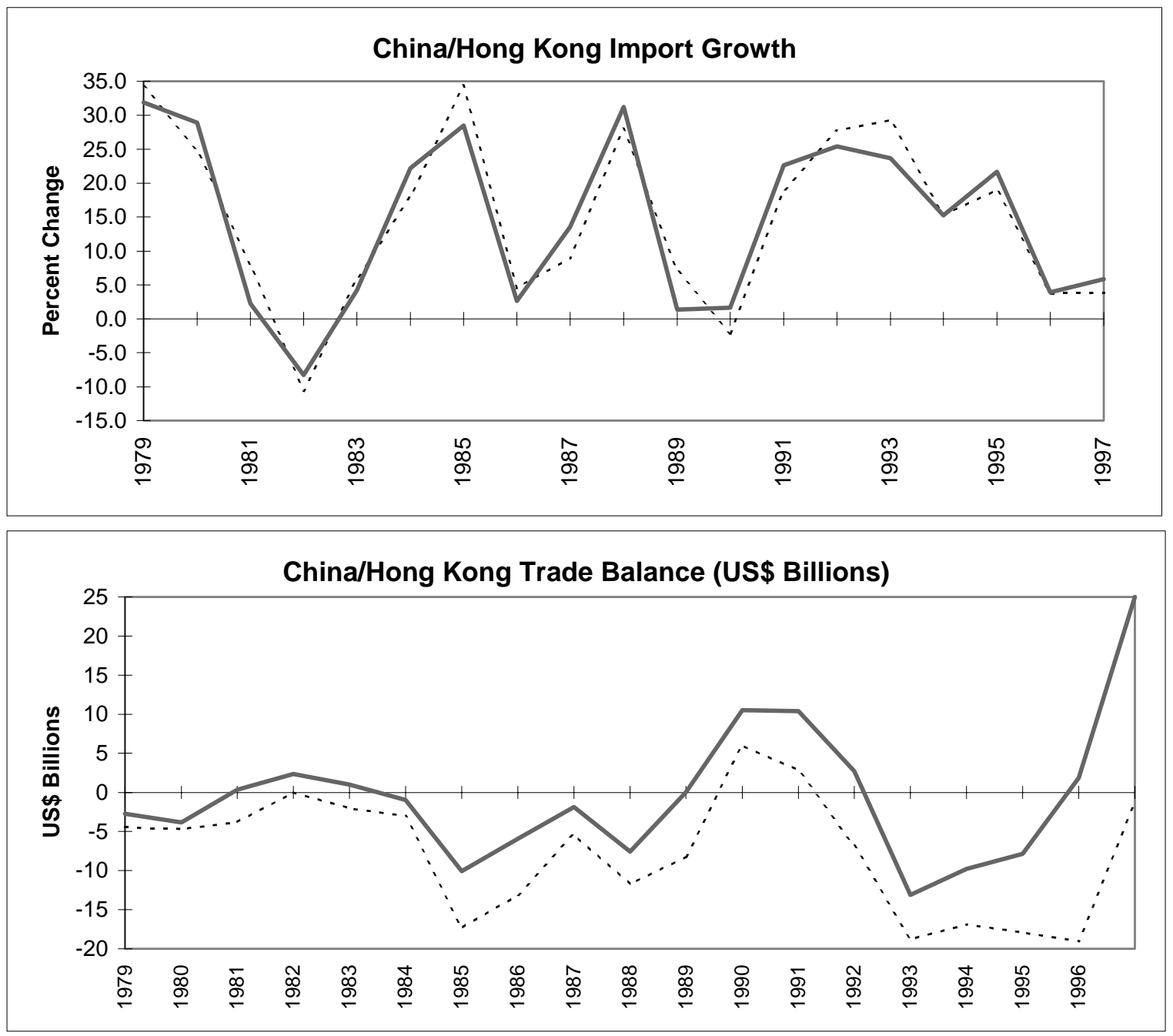

Note: Data for 1997 are through September. 
Figure 6

Measures of China's Risk Premium

International U.S. Dollar Yield Spreads

Chinese, Indonesian, and Korean Government Bonds

Relative to U.S. Treasuries

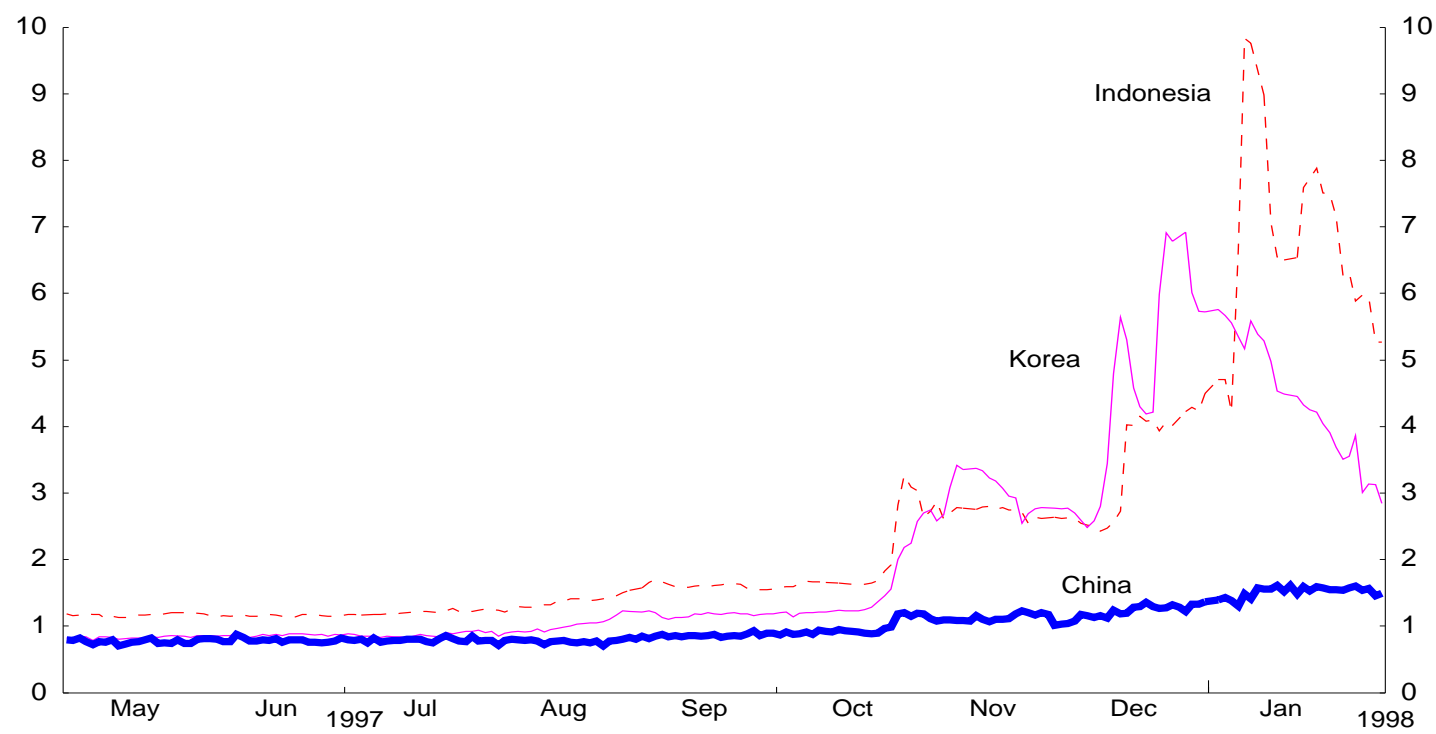

Note: China spread is for bond due $2 / 17 / 04$. Korean and Indonesian bonds are for widely-used financial market benchmark issues, with roughly a 10-year maturity.

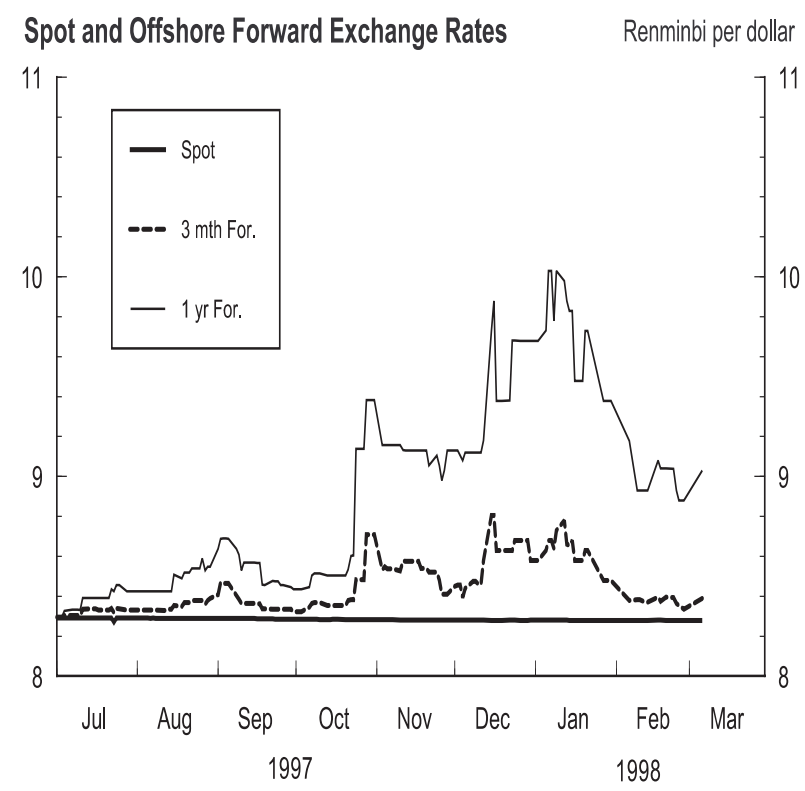

Source: Reuters.

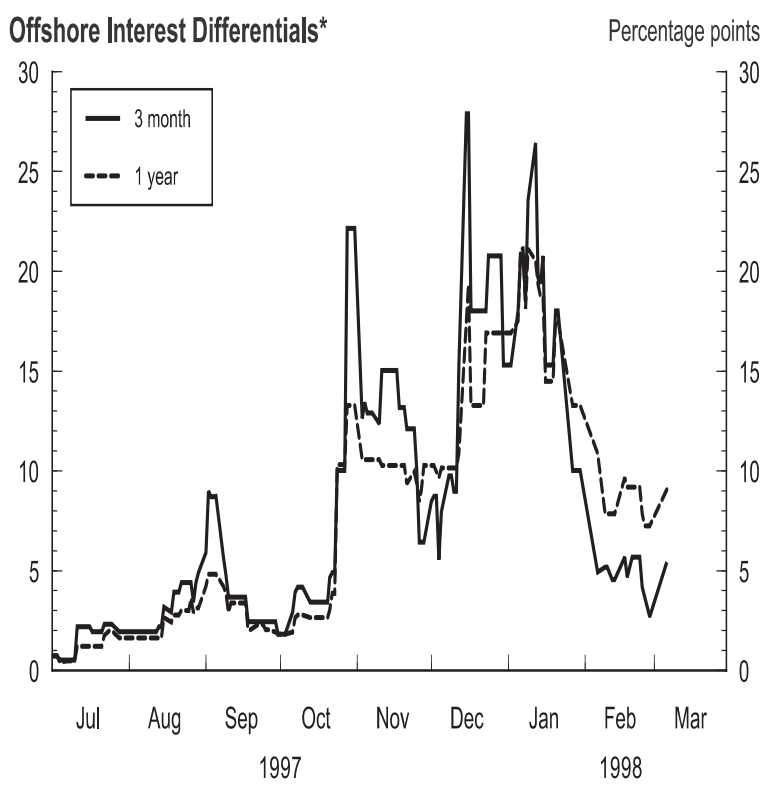

${ }^{*}$ Vis-a-vis U.S. dollar assets, derived from offshore forward exchange rates. 